\title{
The Use of OECD Commentaries as Interpretative Aids - The Static/Ambulatory-Approaches Debate Considered from the Perspective of International Law $^{\star}$
}

DOI 10.1515/ntaxj-2015-0003

Received November 17, 2014; accepted March 15, 2015

\section{Introduction}

Tax administrators, courts and taxpayers frequently resort to Commentaries to OECD Model Tax Conventions on Income and on Capital to express propositions about the proper understanding of tax treaties. From the point of view of the legal justification of such propositions, this practice poses a problem, considering that the legal relevance of OECD Commentaries remains an issue of serious contention among international tax law experts. Most important, international tax law experts have long debated the relevance of changes to OECD Commentaries for the purpose of interpreting previously concluded tax treaties. ${ }^{1}$

Ulf Linderfalk: Professor of International Law at the Faculty of Law, Lund University. Editor-in-Chief of the Nordic Journal of International Law; Email: ulf.linderfalk@jur.lu.se.

Maria Hilling: Associate Professor of Tax Law at the Faculty of Law, Lund University; Email: maria.hilling@jur.lu.se

* Special thanks go to the Torsten Söderberg and Ragnar Söderberg Foundations for the financial support needed to complete this article. 1 See K. Vogel, The Influence of the OECD Commentaries on Tax Treaty Interpretation, Bulletin 2000, pp. 612-616; J. Avery Jones, The Effect of Changes in the OECD Commentaries after a Treaty is Concluded, Bulletin 2002, pp. 102-104; M. Lang and F. Brugger, The Role of the OECD Commentary in Tax Treaty Interpretation, (2008) 23 Australian Tax Forum, pp. 95-108; S. Douma and F. Engelen (eds.), The Legal Status of the OECD Commentaries, IBFD (2008); H., Ault, The Role of the OECD Commentaries in the Interpretation of Tax Treaties, Intertax 1994, pp. 144-148; P. Wattel and O. Marres, The Legal Status of the OECD Commentary and Static or Ambulatory Interpretation of Tax Treaties, European Taxation 2003, pp. 222-235; F. Engelen, Some Observations on the Legal Status of the Commentaries on the OECD Model, Bulletin 2006, pp. 105-109; D. Ward, The Role of Commentaries on the OECD Model in the Tax Treaty Interpretation Process, Bulletin 2006, pp. 97-
The choice is between a static and an ambulatory approach. In a situation in which an interpreter is asked to clarify the meaning of a treaty relative to a particular dispute, if taking a static approach, the interpreter will limit the use of OECD Commentaries to those that existed at the conclusion of the treaty. If taking an ambulatory approach, the interpreter will accept the relevance of any subsequently adopted Commentaries.

As a matter of principle, international tax law experts are generally averse to the idea of an ambulatory approach to the use of OECD Commentaries. ${ }^{2}$ This reluctance seems intimately tied to their understanding of the theoretical framework of the applicable international law. Tax treaties are international agreements between states governed by international law. As such, they are to be interpreted based on the law laid down in Articles 31-33 of the 1969 Vienna Convention on the Law of Treaties (VCLT). ${ }^{3}$ It is the fundamental assumption underlying this law that interpretation is always conducted with a specific purpose-to establish the common intention of treaty parties. International tax law experts find it peculiar that OECD Commentaries can ever help interpreters gain insights into the common intention of parties to a tax treaty, if those Commentaries did not even exist when the treaty was concluded.

Now, surprisingly, as the static/ambulatoryapproaches debate currently stands, most experts would still seem unwilling to discard with the idea of an ambulatory approach completely. The question that the great majority of experts is asking is not if an ambulatory approach should ever be taken, but when it should be taken and why. Professor Lang and Research Assistant Brugger con-

102; R. Vann, Interpretation of Tax Treaties in New Holland, in H. van Arendonk, F. Engelen, and S. Jansen (eds.), A Tax Globalist: Essays in honour of Maarten J. Ellis, IBFD (2005), pp. 152-155; B. Arnold, Tax Treaties and Tax Avoidance: The 2003 Revisions to the Commentary to the OECD Model, Bulletin 2004, pp. 244-260.

2 See e.g. Ward (n. 1), pp. 101-102; Avery Jones (n. 1), p. 102; Lang and Brugger (n. 1), p. 107.

3 UNTS, Vol. 1155, p. 331. 
clude that amendments to OECD Commentaries adopted after the ratification of a tax treaty may be considered in exceptional cases only. ${ }^{4}$ In their view, an ambulatory approach to the Commentaries can be accepted only when there is evidence in OECD reports or draft documents that the post-treaty amendment was already available to treaty negotiators and it is established that they understood draft treaty provisions in the light of those amendments, rather than relying solely on the previously existing Commentaries. Lang and Brugger's reasoning follows from their understanding that post-treaty amendments cannot serve to establish the parties' intentions upon conclusion of a tax treaty.

Professor Vogel advocates a step-by-step approach to decide the relevance of OECD Commentaries when changed after the conclusion of a tax treaty. ${ }^{5}$ According to Vogel, when deciding about the relevance of OECD Commentaries, decisions should be based upon the amount of time since the amendment was inserted. If an amendment has been available for a considerable time, it should be considered decisive for the determination of international tax language, which, in turn, makes it relevant when, according to Article 31, paragraph 1 of the VCLT, an ordinary meaning is attributed to tax treaty terms. If, on the other hand, the amendment is too recent to have influenced the parlor of international tax lawyers, the Commentaries may still serve as a supplementary means of interpretation, subject to the limitations of Article 32 of said Convention.

Professors Wattel and Marres hold the position that post-treaty changes of OECD Commentaries do not have the same democratic legitimacy as those Commentaries that existed at the time of the conclusion of a tax treaty. ${ }^{6}$ In their view, the starting point of interpreters should always be the static approach. As for the classification of OECD

\footnotetext{
4 Lang and Brugger (n. 1), p. 107. It can be noted that Lang states in a more recent publication that "... only the version of the OECD Model and the respective Commentary existing at the time of conclusion of the corresponding DTC can be considered for the interpretation of a DTC that follows the OECD Model, since the DTC negotiators could only have an understanding if the version of the Commentary existing at that point in time. It cannot therefore be assumed that they attached a meaning to a DTC provision which it only acquired in a later version of the Commentary. . . ", M. Lang, Introduction to the Law of Double Taxation Conventions, Linde/IBFD (2013), marginal no. 98.

5 Vogel (n. 1), p. 616 (see also Klaus Vogel on Double Taxation Conventions, Kluwer (1999), Introduction, marginal no. 82 a-82 b). Dahlberg seems to agree with this approach, see M. Dahlberg, Vilket rättskällevärde har kommentarerna till OECD:s modellavtal? in R. Arvidsson, et al (eds.), Festskrift till Gustav Lindencrona, Norstedts (2003) pp. 144-147.

6 Wattel and Marres (n. 1), p. 224.
}

Commentaries, according to Wattel and Marres the Commentaries should be considered, in most cases, a supplementary means of interpretation, in the sense of Article 32 of the VCLT. ${ }^{7}$

Professor Vann is one of the few tax law scholars in favor of applying the ambulatory approach more generally. ${ }^{8}$ He stresses that there are many practical and legal reasons why courts should rely on subsequent OECD Commentaries, and he underlines that, in practice, courts are increasingly more flexible about this whole issue. ${ }^{9}$ Vann's main point is that it is artificial to tie the meaning of tax treaties to specific versions of the Commentaries. During the period of negotiation of a tax treaty-which typically lasts for about two years, but sometimes up to a decadenegotiators will generally participate in OECD work on revisions of the hitherto existing Model Convention and Commentaries. They are well aware of OECD positions and build upon them, although those positions may not yet be public and may not become so until after the treaty is concluded.

The various positions taken in the debate over static/ambulatory approaches illustrate the complexities of the matter and underlines the need for further research. The focus of such research should be on the law laid down in Articles 31-33 of the VCLT. Consequently, it is the purpose of this essay to analyze and explain the general international legal framework represented by those articles. The inquiry will be organized based on two overarching assumptions. First, in our attempt to come to grips with the debate on the use of OECD Commentaries, we will presuppose a need to anchor this debate more firmly in current international law doctrines. As we understand things, there is nothing peculiar about tax treaty interpretation that clearly distinguishes this activity from the interpretation of other treaties between states. Tax treaty interpretation is merely a special case of treaty interpretation in international law generally; hence the many references throughout this essay to general international law and legal practice. Second, as we are convinced, it is a sine qua

7 Wattel and Marres (n. 1), pp. 228-229.

8 Vann (n. 1), pp. 152-155. Arnold holds a similar view, he states that "... the Commentary to the OECD Model is never binding on courts; the Commentary is always relevant, however, and may be of persuasive influence in interpreting a treaty. Courts should take into account any changes to the Commentary made after a treaty was concluded in interpreting the treaty and give them the appropriate weight in the circumstances", Arnold (n. 1), p. 260.

9 Also Zimmer has noticed this development in the case law of Høyesterett (Norwegian Supreme Administrative Court), F. Zimmer, Internasjonal inntektsskatterett, Universitetsforlag (2009), p. 80. 
non of any rational future debate on the use of OECD Commentaries that tax lawyers fully recognize not only the importance of the legal framework represented by Articles 31-33 of the VCLT, but also the theoretical underpinnings of this framework. ${ }^{10}$ This is why a recurrent theme in our analysis will be the role played in the treaty interpretation process of party intention. The questions that we will address are the following.

1. What is the role of party intention in the application of Articles 31-33 of the VCLT, generally?

2. For the purpose of interpreting tax treaty law, how can the use of OECD Commentaries be justified based on international law?

3. Considering the answer to question (2), should a static or an ambulatory approach be taken?

We will address the questions in turn, in Sections 2, 3 and 4 , respectively.

\section{Articles 31-33 of the VCLT and the Role of Party Intention}

\subsection{How to Understand Articles 31-33}

Whenever issues of tax treaty interpretation arise, attention will inevitably focus on the provisions laid down in Articles 31-33 of the 1969 Vienna Convention on the Law of Treaties (VCLT). It will do so partly because Articles 31-33 are not only a source of obligation for the 114 states that are currently parties to the VCLT. ${ }^{11}$ They are also a reflection of the obligations incumbent upon states under general customary international law..$^{12}$ Partly, too, attention will focus on Articles 31-33 because of the second branch of the doc-

10 Vann points out that Articles 31-32 of the Vienna Convention need to be read broadly against a background of a diffuse tradition of interpretation of treaties in international law. Not surprisingly, Vann continues, tax lawyers are prone to treating the terms of these Articles "like a tax statue and interpret them in a literal manner, no doubt relying on Article 31(1) for this purpose!", Vann (n. 1), p. 151. We are inclined to agree with Vann on this point.

11 Multilateral Treaties Deposited with the UN SecretaryGeneral; database available at: http://treaties.un.org/pages/ ParticipationStatus.aspx, statusasat270ctober2014.

12 See e.g. Dispute Regarding Navigational and Related Rights (Costa Rica v. Nicaragua), Judgment of 13 July 2009, ICJ Reports 2009, p. 213, at 237 (para. 47); Sovereignty over Pulau Ligitan and Pulau Sipadan (Indonesia/Malaysia), Judgment of 17 December 2002, ICJ Reports 2002, p. 625, at 645-646 (para. 37); Maritime Dispute (Peru v. Chile), Judgment of 27 January 2014, available only through the webpage of the Court: http://www.icj-cij.org, pp. 26-27 (para. 57); Application of the trine of intertemporal law. ${ }^{13}$ As implied by this doctrine, whoever interprets a treaty shall conform, not with the rules of international law that possibly existed at the time of the conclusion of the treaty, but with the rules that exist at the time of its interpretation. ${ }^{14}$ The customary nature of Articles 31-33 and the doctrine of intertemporal law combine to moderate considerably the effect of the prohibition of retroactive application of the Vienna Convention laid down in Article $4 .{ }^{15}$ If an interpreter is formally prevented from applying Articles 31-33 of the VCLT for the purpose of interpreting a treaty concluded prior to the time that the VCLT became at all applicable in the relations between the treaty parties, then the interpreter is always free to resort to the rules of customary international law reflected in those same articles.

In order to understand the further significance of Articles 31-33 of the VCLT for a discussion of the relevance and importance of OECD Commentaries for the interpretation of tax treaties, a few things must be understood about the theoretical foundation of those articles. More than anything else, we need to understand the role of party intention. To gain this understanding, we need to establish the aim of the treaty interpretation process assumed by Articles 31-33. When tax lawyers describe the relevant international law, they often maintain that Articles 31 and 32 stand for two different approaches to treaty interpretation. ${ }^{16}$ As they articulate it, Article 31 requires the adoption of a textual (or objective) approach whereby, when applying Article 31, interpreters consequently inquire into the meaning of the text of treaties. ${ }^{17}$ Article 32, on the other hand, requires the adoption of a historical intentions

Convention on the Prevention and Punishment of the Crime of Genocide (Bosnia and Herzegovina v. Serbia-Montenegro), Merits, Judgment of 26 February 2007, ICJ Reports 2007, p. 43, at 110 (para. 160).

13 See e.g. Island of Palmas Arbitration, Award of 4 April 1928, UNRIAA, Vol. 2, p. 829, at 845.

14 See e.g. Navigational and Related Rights (n. 19), p. 237 (para. 47). 15 Article 4 reads: "Without prejudice to the application of any rules set forth in the present Convention to which treaties would be subject under international law independently of the Convention, the Convention applies only to treaties which are concluded by States after the entry into force of the present Convention with regard to such States".

16 Ault (n. 1), p. 146; Dahlberg (n. 5), p. 150; Ward (n. 1), p. 99; K. Vogel and R.G. Prokisch, General Report on Subject I: Interpretation of Double Taxation Conventions, Cahiers de droit fiscal international, Vol. 78a (1993), p. 73; F. Weiss, Interpretation of Tax Treaties in Accordance with the Commentaries on the OECD Model Tax Convention under the Vienna Convention on the Law of Treaties, in Douma and Engelen (n. 1), Section 1.4.

17 Ibid. 
(or subjective) approach: when applying Article 32, interpreters inquire into the true intention of the treaty parties. ${ }^{18}$ To support this description, tax lawyers typically refer to the Commentary to the Draft Articles on the Law of Treaties adopted by the International Law Commission in $1966,{ }^{19}$ and submitted as background material to the 1968 and 1969 Vienna Conference. This Commentary is often referred to as "the Commentary on the Vienna Convention" ${ }^{120}$ or its "Official Commentary"21 or again, its "official interpretation".22

This description of Articles 31 and 32 builds on some serious misunderstandings. While those misunderstandings bear directly on the discussion of the relevance of OECD Commentaries as interpretative aids, the description forms a natural starting-point for our further inquiries into the topic. The description can be analyzed as comprising three separate propositions:

1. In the conceptual universe of the VCLT, there is something like a true intention of treaty parties.

2. Depending on whether Article 31 or Article 32 of the VCLT is applied, the aim of interpretation will be different.

3. The 1966 ILC Commentary to the Draft Articles on the Law of Treaties is a convincing authority for the proposition that Articles 31 and 32 assume two fundamentally different approaches to treaty interpretation.

We will comment on all three propositions in turn.

\subsection{The True Intention of Parties is Irrelevant}

The Vienna Convention confers a specific purpose on the treaty interpretation process: to establish what is often referred to as "the common intention of the treaty parties" or merely "the intention of the parties". ${ }^{23}$ Party intention is a

\footnotetext{
18 Ibid.

19 Draft Articles on the Law of Treaties With Commentaries, Report of the International Law Commission on the second part of its seventeenth session and on its eighteenth session, Part II, ILC Yearbook, 1966, Vol. 2, p. 187.

20 See e.g. Ward (n. 1), p. 99.

21 See e.g. Wattel and Marres (n. 1), pp. 225, 228. Vann (n. 1), p. 5, fn. 13.

22 See e.g. Dahlberg (n. 5), p. 150; our translation. In Swedish, this is the expression used: "den officiella tolkningen".

23 See e.g. E. Bjorge, The Evolutionary Interpretation of Treaties (2014), p. 2; I. Brownlie, Principles of Public International Law, $4^{\text {th }} \mathrm{ed}$. (1990), p. 627; P.M. Dupuy, Droit international public (1992), p. 220; C. McLachlan, The Principle of Systemic Integration and Article 31(3)(c)
}

loose concept, of course. Even limiting its use to the context of treaty interpretation, "party intention" can mean many different things. We can mean the referring intention of the treaty parties. If, for example, we inquire into the ordinary meaning of a treaty term such as "The vessels", we may wonder whether parties to the treaty intended that term to refer to any particular vessels or to vessels generically. ${ }^{24}$ In another sense of "party intention", we may mean the intended object and purpose of a treaty provision. If, for example, we inquire into the application of Article 10 of the European Convention on the Protection of Human Rights and Fundamental Freedoms, we may wonder whether by the inclusion of a "right of freedom of expression", parties to the Convention intended to protect the exchange of political ideas and opinions irrespective of their contents or to ensure the proper functioning of democratic society. ${ }^{25}$ "Party intention" may mean the intended relationship between two separate instruments. If, for example, we inquire into the status of a map annexed to a treaty, we may wonder whether or not the parties to the treaty intended that the map be considered an integrated part of the treaty. ${ }^{26}$ Again, "party intention" may mean the intended relationship between a treaty and a subsequent agreement. If, for example, we inquire into the status of a Memorandum of Understanding (MoU), we may wonder whether or not the parties to the MoU intended it to state their agreement concerning the interpretation of some earlier treaty. ${ }^{27}$ To add clarification, instead of merely going along with the inherent ambiguities of "party intention", henceforth in this essay, we will draw on the terminology used by linguistics (or pragmatics, to be more specific). As we phrase it, it is the ultimate purpose of the treaty interpretation process to establish the communicative inten-

of the Vienna Convention, International and Comparative Law Quarterly, Vol. 54 (2005), p. 279, at 287; Oppenheim's International Law, $9^{\text {th }}$ ed., Vol. 1, eds. R. Jennings and A. Watts, (1992), p. 1267; G. Ress, The Interpretation of the Charter, The Charter of the United Nations: A Commentary, (ed.) B. Simma (1994), p. 25, at 30; I. Sinclair, The Vienna Convention on the Law of Treaties, $2^{\text {nd }}$ ed. (1984), p. 115; M. K. Yasseen, L'interprétation des traités d'après la Convention de Vienne sur le droit des traités, Recueil des Cours, Vol. 151 (1976:3), p. 1, at 16. 24 Comp Navigational and Related Rights (n. 12), at pp. 247-248 (paras. 80-84).

25 Comp Refah Partisi (The Welfare Party) and Others $v$ Turkey, ECHR 2003-II, paras. 88-89, 98-99.

26 Comp Guinea-Guinea-Bissau Maritime Delimitation Case, Award of 14 February 1985, ILR, Vol. 77, p. 636, at 664-665 (para. 54).

27 Comp United States-United Kingdom Arbitration Concerning Heathrow Airport User Charges, Award of 30 November 1992, ILR, Vol. 102, p. 216, at 353 (paras. 6.7-6.8). 
tion of the treaty parties-the meaning that the parties intended the treaty to communicate.

For any intellectual process aimed at determining the communicative intention of some treaty parties, it remains a problem that such an intention can only be assumed. Thus, the interpretation of a treaty is no different than the understanding of just any verbal utterance produced by a person or group of persons at a particular occasion, whether orally or in writing. As emphasized by pragmatics, an utterance can be understood only on the assumption that whoever produced it acted rationally. The addressee or addressees of the utterance must assume that in communicating his intention, the utterer acted in conformity with some standard or standards of communication. ${ }^{28}$ An addressee may assume, for example, that an utterer brings only relevant information. ${ }^{29}$ Henceforth in this article, any such assumption made by a reader or a listener in the interpretation of an utterance will be referred to as a communicative assumption. ${ }^{30}$

Now, obviously, different kinds of communicative assumptions may be relevant for the interpretation of different kinds of utterances. Diplomatic notes are not interpreted in the same sense as dinner table discussions, for example. In the specific context of treaty interpretation, international law sets a limit to the use of communicative assumptions. As indicated in the text of Articles 3133 and further confirmed by the practice of international courts and tribunals, the assumptions allowed are those that draw on either one of a limited number of means of interpretation. They include the following: treaty parties arranged so that the treaty conforms to the lexicon, grammar and pragmatic rules of the language used for every authenticated version of it; ${ }^{31}$ treaty parties arranged so that a consistent meaning can be conferred on all words and lexicalized phrases used in the interpreted treaty; ${ }^{32}$ treaty parties arranged so that no norm expressed in the treaty

28 See e.g. D. Sperber and D. Wilson, Relevance. Communication and Cognition (1986); D. Blakemore, Understanding Utterances. Introduction to Pragmatics (1992).

29 Comp the maxims of communicative cooperation suggested by $\mathrm{H}$. P. Grice, Studies in the Way of Words (1989).

30 This terminology builds on the pragmatic literature. See e.g. Sperber and Wilson (n. 28); Blakemore (n. 28). For a more comprehensive treatment of the concept of communicative assumptions in the context of treaty interpretation, see U. Linderfalk, On the Interpretation of Treaties (2007), Ch 2.

31 See e.g. Case Concerning Kasikili/Sedudu Island (Botswana/Namibia), Judgment of 13 December 1999, ICJ Reports 1999, p. 1045, at 1062 (para. 25).

32 See e.g. Navigational and Related Rights (n. 12), p. 239 (para. 54). logically contradicts any other; ${ }^{33}$ treaty parties arranged so that no part of the treaty comes out as redundant; ${ }^{34}$ treaty parties arranged so that the application of the treaty results in the realization of its object and purpose; $;^{35}$ treaty parties arranged so that the treaty does not derogate from any other international legal norm applicable in the relationship between them; ${ }^{36}$ treaty parties arranged so that when the treaty expressly limits the scope of a generically defined class of referents, it excludes all other referents belonging to this class. ${ }^{37}$

If the teaching of pragmatics is correct, then treaty interpretation remains entirely dependent on the use of communicative assumptions. This observation tells us something important about the role of party intention for the treaty interpretation process. While international law continues to uphold the idea of a communicative intention of treaty parties, for the application of Articles 31-33, it does not matter whether, in the case of a particular treaty, there is in fact something like a communicative intention. A communicative intention is always assumed. Consequently, in the conceptual universe of the VCLT, "the common intention of the treaty parties" remains a rational construct. This has to be constantly remembered, especially when discussing the importance of OECD Commentaries for interpretation purposes. If any person maintains that some OECD Commentaries either reflect or do not reflect the actual intention of the parties to some double taxation convention, ${ }^{38}$ we would have to be utterly skeptical about this suggestion. For the purposes of interpreting a tax treaty, from the perspective of the law laid down in Articles 31-33 of the VCLT, whether or not the Commentaries reflect the actual intention of the treaty parties is irrelevant.

33 See e.g. Case of Soering v. The United Kingdom, Judgment of 7 July 1989, available through the HUDOC database: http://hudoc.echr.coe. int, p. 33 (para. 101) and p. 34 (para. 103).

34 See e.g. Case Concerning Application of the International Convention on the Elimination of All Forms of Racial Discrimination (Georgia v. Russian Federation), Preliminary Objections, Judgment of 1 April 2011, as of yet, the decision is available only through the webpage of the Court: http://icj-cij.org, paras.133--134.

35 See e.g. Kasikili/Sedudu Island (n. 31), p. 1072-1073 (para. 43). 36 See e.g. Award in the Arbitration regarding the Iron Rhine ("Ijzeren Rijn") Railway between the Kingdom of Belgium and the Kingdom of the Netherlands, Decision of 24 May 2005, UNRIAA, Vol. 27, p. 35, at pp. 72-73 (para. 79).

37 See e.g. Navigational and Related Rights (n. 12), p. 241 (para. 61). 38 See e.g. Klaus Vogel on Double Taxation Conventions (n. 5), Introduction, paras. 82(a) and (b); M. Lang, Later Commentaries of the OECD Committee on Fiscal Affairs, Not to Affect the Interpretation of Previously Concluded Tax Treaties, Intertax, Vol. 25, Issue 1, p. 7, at 78; Lang and Brugger (n. 1), p. 02. 
All that matters is whether interpreters can justify their use of the Commentaries based on this same law.

\subsection{Articles 31 and 32 Assume One Common Approach to Interpretation}

The position adopted in Sections 2.2 assumes that it is the aim of every act of treaty interpretation-whether based on Article 31 or Article 32 of the VCLT-to determine the communicative intention of treaty parties. Not all lawyers seem willing to accept this assumption. According to some, while in applying Article 32, interpreters inquire into the true intention of treaty parties, Article 31 is applied for the purpose of establishing "the meaning of the text of the treaty". ${ }^{39}$ To assess this suggestion, we first need to clarify it, as the "the meaning of the text of a treaty" is a term that can be used to stand for various things. ${ }^{40}$ First, it can be used to stand for the utterance meaning of the treaty-the meaning that the parties intend the treaty to communicate. Second, it can be used to stand for the sentence meaning of the treaty, that is, the meaning to be conferred on the treaty according to the lexicon and grammar of the language or languages in which the treaty was authenticated. Third, it can be used to stand for the subjective understanding of the treaty-the actual response evoked in each and every reader.

No lawyer can possibly argue that it is the aim, when applying Article 31 of the VCLT, to establish "the meaning of a text of a treaty" and speak, at the same time, about the meaning of the treaty text as the equivalent of its subjective understanding. This position would exclude all talk about legally correct or incorrect interpretations; every understanding of a treaty would be correct by definition. For those who argue that Articles 31 and 32 stand for two different approaches to interpretation, it would seem equally difficult to speak about the meaning of the text of a treaty as the equivalent of its utterance meaning, since this definition presupposes that the aim pursued by an interpreter when applying Article 31 is exactly the same as the aim pursued when applying Article 32. As for the remaining option-that the meaning of the text of a treaty is the equivalent of its sentence meaning-it sits poorly with the wording of Article 31. If it is the aim, when applying Article 31, to establish the sentence meaning of a treaty, there is no good reason why interpreters should inquire into anything other than its ordinary meaning. Article 31, however, does

39 For references, see n. 16.

40 See, similarly, Linderfalk (n. 30), pp. 29-33. not stop there. It also requires that interpreters take into account, for example, the object and purpose of the treaty; other provisions of the treaty, including its preamble and possible annexes; any subsequent practice in the application of the treaty that establishes the agreement of the parties regarding its interpretation; and relevant rules of international law applicable in the relations between the parties. This injunction clearly assumes that interpreters do more than establish the meaning of a treaty according to the relevant lexicon and grammar.

\subsection{The 1966 ILC Commentary Has Little Authority}

To support their suggestion that Articles 31 and 32 of the VCLT presuppose the adoption of two fundamentally different approaches to treaty interpretation, tax law scholars typically refer to the Commentary to the Draft Articles on the Law of Treaties adopted by the International Law Commission (ILC) in $1966 .^{41}$ An oft-quoted passage is the following:

[T]he starting point of interpretation is the elucidation of the meaning of the text, not an investigation $a b$ initio into the intentions of the parties. ${ }^{42}$

Such reasoning fails to convince, for two reasons. First, it builds upon a highly questionable interpretation of the ILC Commentary. When the above-quoted passage is set into context, it reads rather differently:

The article as already indicated is based on the view that the text must be presumed to be the authentic expression of the intention of the parties; and that, in consequence, the starting point of interpretation is the elucidation of the meaning of the text, not an investigation $a b$ initio into the intentions of the parties. ${ }^{43}$

The mere wording of this Commentary would seem enough to discard the idea that, according to the then-view of the ILC, Article 31 stands for something fundamentally different than Article 32. The natural interpretation is that the ILC considered both articles to be equally vehicles in the search for the communicative intention of treaty parties. If there ever was a difference between Articles 31 and 32, it

41 The 1966 Commentaries must not be confused with any earlier Commentaries provisionally adopted by the ILC in 1962, 1963, and 1964, respectively.

42 Draft Articles on the Law of Treaties With Commentaries (n. 19), p. 220.

43 Ibid. 
was only because, typically, the text of a treaty (or rather its ordinary meaning) gave a more reliable insight into that intention than supplementary means of interpretation.

Second, on a more formal note, the 1966 ILC Commentary has little authority for the understanding of Articles 31 and 32 of the VCLT. The ILC is a subsidiary organ of the UN General Assembly. Its particular task is to work for the codification and progressive development of international law. ${ }^{44}$ Typically, for a long time, this task was fulfilled following an established procedure: the Commission would list topics suitable for codification; on the basis of careful studies of relevant practice, following lengthy discussions within the Commission, the Commission would adopt a set of final draft articles, which, together with an accompanying Commentary, would be passed on to the General Assembly for further action. The General Assembly, in turn, would typically convene a diplomatic conference, which would negotiate on the basis of the ILC draft articles; it would make the necessary amendments or additions; it would possibly adopt a treaty that could be signed and ratified or acceded to by states. This was the procedure followed in the case of the conclusion of the VCLT. The 1966 Commentary, together with the final draft articles adopted by the ILC, were part of the background material supplied to all Vienna Conference participants. ${ }^{45}$

Although the Commentary as such is not part of the minutes of the Conference, it clearly reflects on at least parts of the long process of drafting of the Vienna Convention, and it would therefore seem odd not to treat it as part of the preparatory work of the VCLT. ${ }^{46}$ This is not to say, of course, that the Commentary determines the understanding of the VCLT in the same way as commentaries in some jurisdictions determine the meaning of tax law legislation. The ILC Commentary is a supplementary means of interpretation. As such, according to Article 32, it may determine the meaning of the VCLT, but only on the condition that the application of Article 31 leads to a result that is either ambiguous or obscure, or manifestly absurd or unreasonable. In the case of the particular issue of in-

44 Comp Art. 1 of the Statute of the International Law Commission. 45 Documents of the Conference, United Nations Conference on the Law of Treaties, First and second sessions, Vienna, 26 March-24 May 1968 and 9 April-22 May 1969, Official Records, p. 7.

46 It must be remembered, of course, that the 1966 Commentaries are not the result of any action of states. ILC members are not state representatives, but act in the capacity of international law experts. Comp Art. 2 of the Statute of the International Law Commission. Consequently, the interpretative value of the Commentaries would always inevitably turn on the assumption that states read and reflected upon them. terpretation at hand-whether or not Articles 31 and 32 stand for two fundamentally different approaches to treaty interpretation-the application of Article 31 does not lead to such a result. On the contrary, as we insist, the wording of Article 31 clearly shows it to be the purpose of Article 31 to establish the communicative intention of treaty parties. Otherwise, why would Article 31 instruct that interpreters of a treaty consider: "any agreement relating to the treaty which was made between all the parties in connection with the conclusion of the treaty"; 47 "any instrument which was made by one or more parties in connection with the conclusion of the treaty and accepted by the other parties as an instrument related to the treaty"; 48 "any subsequent agreement between the parties regarding the interpretation of the treaty or the application of its provisions"; 49 "any subsequent practice in the application of the treaty which establishes the agreement of the parties regarding its interpretation"; $;^{50}$ and "any relevant rules of international law applicable in the relations between the parties" ${ }^{51}$

\section{Using OECD Commentaries as a means of interpretation}

\subsection{OECD Commentaries Are Not Legally Binding, as Such}

Today's tax treaty network consists of more than 3,000 treaties, which are largely similar in policy, and even in language..$^{52}$ This development is due mainly to the work of the OECD with its Model Tax Convention on Income and on Capital and Commentaries. ${ }^{53}$ OECD member states have largely conformed to this Model when concluding and amending tax treaties. ${ }^{54}$ The original purpose of

47 Art. 31, para. 2(a); italics are added.

48 Art. 31, para. 2(b); italics are added.

49 Art. 31, para. 3(a); italics are added.

50 Art. 31, para. 3(b); italics are added.

51 Art. 31, para. 3(c); italics are added.

52 R. Avi-Yonah, International Tax as International Law, Cambridge University Press (2007), p. 3.

53 The Organisation for European Economic Co-operation (OEEC), the predecessor of the Organisation for Economic Co-operation and Development (OECD), took over the work of the League of Nations after World War II of establishing a Model treaty. For an overview of the historical background, see Introduction to the OECD Commentaries, paras. 4-11.

54 Introduction to the OECD Commentaries, para. 13. 
tax treaties was to prevent international double taxation, which occurs because of overlaps in domestic tax claims. If the resident of one jurisdiction earns income in another jurisdiction (the source jurisdiction), for instance, both jurisdictions may tax that income under their domestic tax legislations. Tax treaties address such overlaps in order to minimize harmful effects on cross-border economic activities. ${ }^{55} \mathrm{An}$ additional purpose of tax treaties is to counteract tax evasion and avoidance-an issue that has gained importance during the last decade. ${ }^{56}$

OECD published its first Model in 1963 and completed a first revision in 1977. In 1992, the OECD Model and Commentaries underwent further revision. At this time, the OECD moved to a loose-leaf ongoing revision process. Changes have since been made in intervals of approximately two to three years. ${ }^{57}$ It can be observed, however, that while OECD Commentaries are updated regularly, neither the provisions of the OECD Model Convention nor tax treaties based upon it typically change at the same pace. ${ }^{58}$ A tax treaty is generally expected to exist for 10 to 20 years or longer without changes. ${ }^{59}$ Even though Model changes are agreed upon multilaterally, it takes substantial time before such changes are reflected in most tax treaties, as the vast majority of tax treaties are bilateral. ${ }^{60}$ It would require decades for a state to renegotiate its entire tax treaty network. Because tax treaties are negotiated over a long period, the current tax treaty network is not well synchronized with the current OECD Model. Within the OECD's Base Erosion and Profit Shifting project, this difficulty to implement Model changes into the actual tax treaty network swiftly is considered severely problematic. ${ }^{61}$

The OECD organ responsible for the work on the Model and Commentaries is the Committee on Fiscal Affairs (CFA). The CFA consists partly of representatives of governments of OECD member states and partly of appointed ex-

55 Introduction to the OECD Commentaries, para. 5.

56 Since 2003, it has been stated explicitly in the OECD Commentaries that it is a purpose of tax treaties to prevent tax avoidance, see Commentaries to Article 1, para. 7.

57 Changes have taken place in 1992, 1994, 1995, 1997, 2000, 2003, 2005, 2008, 2010, and 2014. Simply finding the version existing at the time the tax treaty was concluded is not always an easy task.

58 Douma and Engelen (n. 1), p. 4.

59 Vann (n. 1), p. 147. According to Sasseville, in average tax treaties concluded between OECD member states remain unchanged for 15 years, J. Sasseville, The Role of Tax Treaties in the $21^{\text {st }}$ Century, Bulletin 2002, p. 247.

60 OECD/G20 Base Erosion and Profit Shifting Project, Developing a Multilateral Instrument to Modify Bilateral Tax Treaties, OECD (2014), p. 12.

61 Ibid., p. 11-14. perts, who are commonly recruited among staff members of Ministries of Finance and tax authorities, many of whom would act as tax-treaty negotiators on other occasions. As pointed out by Professor Vann, from the viewpoint of the private sector, OECD Commentaries may generally be regarded as pro-government. ${ }^{62}$ Still, as Vann is quick to admit, the private sector has a larger influence on the work of the CFA than on the development of most other international standards.

As highlighted in the Introduction to the OECD Commentaries, the Commentaries are viewed by tax treaty interpreters in all camps as an important interpretative reference, and increasingly so. ${ }^{63}$ It should be noted that, in many cases, OECD Commentaries go well beyond a mere explanation of the meaning of terms found in the Model Convention. They provide the background of provisions, as well, and explain why certain provisions were considered desirable or necessary. ${ }^{64}$ Commentaries, like tax treaties, are the result of compromises. ${ }^{65}$ They are generally phrased using relatively flexible language, so as to accommodate a wide range of opinions. Consequently and obviously, the precise meaning of Commentaries will often remain the subject of considerable debate. ${ }^{66}$

OECD Commentaries contain reservations and observations made by OECD member states. Reservations relate to articles of the Model. ${ }^{67}$ In making a reservation, the reserving state declares its intention not to insert particular provisions of the Model in future tax treaties. Observations relate to particular passages of the Commentaries. When a member state of the OECD cannot agree with the interpretation of the Model espoused in the Commentaries, it may add to those Commentaries an observation to this effect. ${ }^{68}$ Consequently, observations do not express disagreement with the text of the Model Convention, but indicate the way observing states understand it.

The legal relevance of OECD Commentaries is referred to as one of the major unresolved issues in modern in-

62 Vann (n. 1), p. 158.

63 Introduction to the OECD Commentaries, para. 29.3.

64 M. Ellis, The Influence of the OECD Commentaries on Treaty Interpretation-Response to Prof. Dr. Klaus Vogel, Bulletin 2000, p. 618.

65 Vann (n. 1), p. 158.

66 B. Arnold, The Interpretation of Tax Treaties: Myth and Reality, Bulletin 2010, p. 8 and Ellis (n. 64), p. 618.

67 Introduction to the OECD Commentaries, para. 31.

68 Introduction to the OECD Commentaries, para. 30. 
ternational tax law. ${ }^{69}$ Experts agree that OECD member states have no legal obligation to accept the provisions of Commentaries for the purpose of the interpretation of their tax treaties, not even in cases where treaty provisions were phrased based directly on the OECD Model, down to the last word. ${ }^{70}$ At the same time, there is a consensus among international tax experts that OECD Commentaries are legally relevant. The suggested basis for this conclusion varies greatly, however. ${ }^{71}$ Of course, there is nothing to prevent states from dealing explicitly with the significance of the OECD Model and Commentaries in their treaties. ${ }^{72}$ That option is, however, rarely used..$^{73}$

No provision in the OECD Model Convention indicates a preference for either the static or the ambulatory approach to the use of Commentaries in the interpretation of tax treaties. In reference to Article 3, paragraph 2 of the OECD Model, it has been clarified, by changes in the 1992 Commentaries and in the 1995 Model, that an ambulatory approach to domestic law is preferred. ${ }^{74}$ According to the

69 N. Blokker, Skating on Thin Ice? On the Law of International Organizations and the Legal Nature of the Commentaries on the OECD Model Tax Convention, in Douma and Engelen (n. 1), p. 24.

70 Douma and Engelen (n. 1).

71 See Section 1 of this article.

72 Vogel and Prokisch (n. 16), p. 65.

73 See e.g. para. 8 of the Protocol of 16 July 2009 of the tax treaty between Belgium and Isle of Man, which states: "The provisions of the Agreement which are drafted according to the corresponding provisions of the OECD Model Convention on Income and on Capital shall generally be expected to have the same meaning as expressed in the OECD Commentary thereon. The understanding in the preceding sentence will not apply with respect to the following:

a) any reservations or observations to the OECD Model or its Commentary by either Party;

b) any contrary interpretations in this Protocol;

c) any contrary interpretation in a published explanation by one of the Parties that has been provided to the competent authority of the other Party prior to the entry into force of the Agreement;

d) any contrary interpretation agreed on by the competent authorities after the entry into force of the Agreement.

The OECD Commentary-as it may be revised from time to timeconstitutes a means of interpretation in the sense of the Vienna Convention of 23 May 1969 on the Law of Treaties".

An exchange of notes (19 January 1971) to the 1971 tax treaty between Switzerland and Japan, stated: "... shall take into consideration the rules as set out in paragraph 2 of Article 4 of the Draft Double Taxation Convention on Income and Capital of the Organisation for Economic Cooperation and Development".

74 Introduction to the OECD Commentaries, para. 35; OECD Commentaries on Article 3, para. 11 and Vann (n. 1) p. 151.
CFA, the ambulatory approach to Commentary updates is to be applied generally. ${ }^{75}$

\subsection{OECD Commentaries Are Not Legally Binding Because of Estoppel or Acquiescence}

Professor Frank Engelen has vehemently argued that member states of the OECD are legally bound by OECD Commentaries because of estoppel or acquiescence. ${ }^{76}$ Consequently, he concludes that OECD Commentaries may be used for interpretation purposes, based on Article 31, paragraph 2(a) of a the VCLT. ${ }^{77}$ According to this provision, the interpretation of treaty shall consider "[a]ny agreement relating to the treaty which was made between all the parties in connexion with the conclusion of the treaty". The argument fails to convince, for two reasons.

First, as Professor Hugh Thirlway has aptly explained, it is too general. Whether, because of acquiescence or estoppel, a party to a tax treaty is bound by a document, such as an OECD Commentary, can be determined based only on the particular circumstances of the conclusion of each particular treaty. ${ }^{78}$ However, even if we interpret Professor Engelen's suggestion to mean that, depending on the particular circumstances of the conclusion of a treaty, parties may be bound by an OECD Commentary because of acquiescence or estoppels, then because of the meaning of "acquiescence" and "estoppel" in international legal language, serious objections would still have to be raised against it. "Acquiescence" and "estoppel" do not mean just silence or inaction. As the International Court of Justice explained in Temple of Preah Vihear (I):

[T] he principle [of estoppels] operates to prevent a State contesting before the Court a situation contrary to a clear and unequivocal representation previously made by it to another State, either expressly or impliedly, on which representation the other State was, in the circumstances, entitled to rely and in fact did rely,

75 Introduction to the OECD Commentaries, paras. 3, 33-36. For criticism of this statement, see Ellis (n. 64), p. 618.

76 See Engelen, 2006 (n. 1); F. Engelen, How "Acquiescence" and Estoppel can Operate to the Effect that the States Parties to a Tax Treaty Are Legally Bound to Interpret the Treaty in Accordance With the Commentaries on the OECD Model Tax Convention, in Douma and Engelen (n. 1).

77 Engelen, 2006 (n. 1), p. 109; Engelen, 2008 (n. 1), Sections 2.2 and 3.1.

$78 \mathrm{H}$. Thirlway, The Role of the International Law Concepts of Acquiescence and Estoppel, in Douma and Engelen (n. 1), p. 29, at 32. 
and as a result that other State has been prejudiced or the State making it has secured some benefit or advantage for itself. ${ }^{79}$

Admittedly, the meaning of acquiescence is somewhat vaguer. It has its basis in the principle of good faith. Consequently, as explained by Judge Wolfrum in his $M / V$ Saiga (No. 2) Separate Opinion:

It is ... common ground that the acquiescing State must have remained inactive although a protest or action would have been required. ${ }^{80}$

This observation explains the problem with Professor Engelen's suggestion. It assumes a specific type of situation: that circumstances of the conclusion of a tax treaty call for a reaction of some kind, lest parties wish to be bound by the OECD Commentary that existed at the time. Given what we know about the process of negotiation of tax treaties generally, this seems to be requiring far too much.

Second, there is something inherently inconsistent about Professor Engelen's argument. On the one hand, if tax treaty parties were legally bound by OECD Commentaries, wholly or in part, then whatever those Commentaries say about the meaning or application of tax treaties would apply. There would be no need to invoke Article 31, paragraph 2(a) of the VCLT or any other provision of the Convention for that matter. Parties would have to apply the Commentaries, irrespective of whether or not their use would be defendable under Articles 31-32 of the VCLT. This conclusion follows from the mere fact that Articles 31-32 are jus dispositivum: the articles apply only insofar as parties to a treaty have not agreed differently. If, on the other hand, OECD Commentaries would come within the scope of the application of Article 31, paragraph 2(a), they would still be only one means of interpretation among many others. Interpreters would be allowed to use OECD Commentaries for interpretation purposes, but they would not necessarily determine the meaning of any tax treaty.

If we reject Professor Engelen's suggestion and accept the conclusion that OECD Commentaries are nonbinding under international law, then any further discussion of the role of such Commentaries for the interpretation of tax treaties would have to be focused instead on their use as means of interpretation in the sense of Articles 31-33

79 Case Concerning the Temple of Preah Vihear (Cambodia v. Thailand), Merits, Judgment of 15 June 1962, ICJ Reports 1962, p. 6, at 143144; italics are added.

80 The M/V "Saiga" (No. 2) Case (Saint Vincent and the Grenadines v. Guinea), Judgment of 1 July 1999, Separate Opinion of Vice-President Wolfrum, available through the webpage of the Tribunal: https:// www.itlos.org, para.43. of the VCLT. As Professor Klaus Vogel has stated, "the Vienna Convention offers several aspects under which the OECD Commentaries may become relevant for interpreting tax treaties" ${ }^{81}$ We are inclined to agree with this proposition, of course. We choose to see it, not as the end of all discussion on the matter, however, but as a spur toward further careful studies of the law laid down in the VCLT. In our opinion, in order to understand the importance of OECD Commentaries and to have a meaningful discussion on the proper approach in tax treaty interpretation to the use of such Commentaries when changed, we need to define more specifically the aspects of relevance referred to by Professor Vogel. Consequently, in the subsequent Sections 3.3-3.4 of this essay, we will attempt to do just that. How can the use of OECD Commentaries be justified based on Articles 31-33 of the VCLT? This is the question we aim to answer. It should be noted that throughout this inquiry, examples of tax treaty interpretation done in domestic courts are not provided for the purpose of substantiating conclusions concerning the possible justification of the use of OECD Commentaries. Examples are provided merely to illustrate conclusions made on other grounds.

\subsection{What May Work as a Justification for a Use of OECD Commentaries?}

In this essay, we obviously do not consider the interpretation of any specific term or provision of a tax treaty relative to the concrete facts of any given dispute. Rather, we consider the use of OECD Commentaries for the purpose of interpreting tax treaties generally. This means that our answer to the question of justification posed must be relatively flexible. As we will conclude, depending on the situation, justification of the use of OECD Commentaries may be found in several provisions of the VCLT.

First, OECD Commentaries may help to determine "the ordinary meaning" of the terms of a tax treaty in the sense of Article 31, paragraph $1 .^{82}$ In the terminology of the VCLT, the "ordinary meaning" refers to the meaning to be ascribed to treaty terms according to conventional language. ${ }^{83}$ Consequently, the relevant means of interpretation are the lexicon, the grammar, and the pragmatic rules of the language or languages used for the authenticated version or versions of a treaty. As confirmed by studies of the practice of international courts and tribunals, every

81 Vogel, 2000 (n. 1), p. 614.

82 Similarly, see e.g. Wattel and Marres (n. 1), p. 226.

83 See Linderfalk (n. 30), p. 62. 
possible conventional language counts. ${ }^{84}$ This is important to remember, especially in those frequently occurring cases where a tax treaty term has both an everyday meaning and a technical meaning defined by international tax language. According to the VCLT, in such a case, the ordinary meaning of the term will not automatically be determined based on the latter only, as suggested by some tax law scholars, ${ }^{85}$ but rather, will be considered ambiguous. Whether the one or the other ordinary meaning should be adopted will be decided in further stages of the interpretation process.

Normally, the relevant elements of a conventional language can be established by consulting such indirect evidence as dictionaries and grammar books. ${ }^{86}$ In judicial proceedings, especially in the case of treaties using technical language, expert testimony will have to be relied upon occasionally. For example, arbitrators of the US-Iran Claims Tribunal used sworn affidavits by banking experts to establish if, according to the ordinary meaning of the 1981 Algiers Declaration, "all funds" on a security account placed with the Central Bank of Algeria should be interpreted to include interest earned on this same account. ${ }^{87}$ Sometimes, when a court or tribunal inquires into the ordinary meaning of a term of a treaty, it may be necessary and appropriate for it to survey the usage of this term directly, as, for example, by looking into the language of other treaties and international instruments. In Namibia, the International Court of Justice relied upon provisions of the Charter of the UN and resolutions adopted by the UN General Assembly to establish the ordinary meaning of the mandate over South-West Africa entrusted by the League of Nations to South Africa in $1919 .{ }^{88}$ In Kasikili/Sedudu Island, this same court used a resolution adopted by the Institut de droit international to establish the ordinary meaning of an agreement concluded in 1890 by Great Britain and Germany. ${ }^{89}$ Similarly, in AAPL v. Sri Lanka, an ICSID tribunal considered the language of two treaties concluded

\footnotetext{
84 For further references, see ibid, pp. 67-73.

85 For a contrary opinion, see Klaus Vogel on Double Taxation Conventions (n. 5), Introduction, para. 70.

86 See e.g. Guinea-Guinea-Bissau Maritime Delimitation (n. 26), p. 662 (para. 49).

87 Decision with regard to issues arising in connection with the establishment and operation of the security account, Case A/1, Separate opinion of members of the tribunal Aldrich, Holtmann, and Mosk, International Legal Materials, Vol. 22, p. 591, at 505-506.

88 Legal Consequences for States of the Continued Presence of South Africa in Namibia (South-West Africa) Notwithstanding Security Council Resolution 276 (1970), Advisory Opinion 21 June 1971, ICJ Reports 1971, p. 16, at pp. 31-33 (paras. 53-54).

89 Kasikili/Sedudu Island (n. 31), p. 1062 (para. 25).
}

between Italy and Venezuela and between Italy and United States to establish the ordinary meaning of a treaty concluded between Sri Lanka and the UK. ${ }^{90}$

Prévost Car nicely illustrates the use by a court of OECD Commentaries to establish the ordinary meaning of a tax treaty term. ${ }^{91}$ A Canadian court decided the case in 2008. Attention focused on the meaning of "beneficial owner" in Article 10, paragraph 2 of the Tax Treaty concluded in 1986 between Canada and the Netherlands, based on the 1977 OECD Model. ${ }^{92}$ The treaty contained no definition or explanation of this expression. To establish its meaning, the Court turned to English, Canadian and French dictionaries. ${ }^{93}$ The Dutch version of the treaty used for beneficial owner the term uiteindelijk gerechtigde, and the Court relied on legal literature to translate this term into English. ${ }^{94}$ It used the 1977 OECD Commentaries to Article 10, paragraph 2 of the corresponding provision in the Model to conclude that the expression was to be given an international fiscal meaning, rather than any meaning derived from the domestic laws of the contracting states. ${ }^{95}$ Thus, the Court used OECD Commentaries to establish the ordinary meaning of the terms of the treaty in much the same way as it used English, Canadian, and French dictionaries.

Second, OECD Commentaries may help determine the "object and purpose" of a tax treaty in the sense of Article 31, paragraph 1 of the VCLT. ${ }^{96}$ The "object and purpose" of a treaty means its intended telos (in the singular) or tele (in the plural)-the one or several end results that the parties to the treaty intended to achieve by applying it. ${ }^{97}$ Like the communicative intention of treaty parties, the object and purpose of a treaty can be only assumed. This observation raises an important issue of justification. How can interpreters justify an assumption as to what might possibly be the object and purpose of a treaty?

Typically, when an international court or tribunal refers to the object and purpose of an interpreted treaty, it relies upon elements of the text of this same treaty. In

90 Asian Agricultural Products Ltd. v. Republic of Sri Lanka, Award of 27 June 1990, ILR, Vol. 106, p. 417, at 443-444 (paras. 48-49).

91 The Queen v. Prévost Car Inc. [2008] FCA 57.

92 This tax treaty was concluded in 1986.

93 The Queen v. Prévost Car Inc. [2008] FCA 57, paras. 72-80.

94 Ibid., para. 81.

95 Ibid., para. 96.

96 Similarly, see e.g. Wattel and Marres (n. 1), p. 226.

97 Contrary to what the wording of Article 31, paragraph 1 may suggest, if several objects and purposes are conferred on a treaty, they may all be used for the purpose of its interpretation. For a further discussion of this issue, see Linderfalk (n. 30), pp. 211-217. 
Guinea-Guinea-Bissau Maritime Delimitation, for example, the Court of Arbitration referred to frequent use in a Convention of words such as "possession" and "territory", and to the complete absence of "waters", "maritime" and "territorial sea", to show that no delimitation of maritime areas was ever intended. ${ }^{98}$ Albeit not common, practice would seem to accept that inferences can also be drawn on the basis of facts external to a treaty, such as its preparatory work or an earlier treaty used as background material in negotiations. To illustrate, in Kasikili/Sedudu Island, to establish the object and purpose of Article II of a Treaty concluded by Great Britain and Germany in 1890, the International Court of Justice referred to the fact that the disputed passage had been introduced upon the initiative of the latter party. ${ }^{99}$ In Oil Platforms (Preliminary Objections), to establish the object and purpose of Article I of the 1955 American-Iranian Treaty of Amity, Economic Relations, and Consular Rights, this same Court relied upon earlier treaties of friendship and commerce or economic relations, concluded by the US Government with other states. ${ }^{100}$ Such a liberal stance squares well with the VCLT, which explicitly does not limit the determination of the object and purpose of a treaty to any particular means of interpretation. Consequently, there is no reason to exclude the relevance of OECD Commentaries for the determination of the object and purpose of tax treaties just because they are not part of any such treaty.

The Garron case can be used to illustrate how courts use OECD Commentaries for the purpose of establishing the object and purpose of tax treaties. ${ }^{101}$ A Canadian Court decided the case in 2009. The main question was the issue of trust residence under the Tax Treaty concluded in 1980 between Canada and Barbados, based on the 1977 OECD Model. In support of taxation in Canada, the Court considered the possibility of invoking the Canadian General Anti-Abuse Provision in section 245 of the Income Tax Act. In analyzing the arguments brought before it, and more specifically, the argument that it was a situation of abuse of the Tax Treaty, the Court turned to the OECD Commentaries existing at the time of the negotiation and conclusion of the tax treaty. It inferred from those Commentaries

98 Guinea-Guinea-Bissau Maritime Delimitation (n. 26), p. 665 (para. 56).

99 Kasikili/Sedudu Island (n. 31), p. 1074 (para. 45).

100 Oil Platforms (Islamic Republic of Iran v. United States, Preliminary Objections, Judgment of 12 December 1996, ICJ Reports 1996 (II), p. 803, at $814-815$ (para. 29).

101 The Queen v. Garron [2009] TCC 450. This case was later appealed to the Supreme Court of Canada. that tax treaties are not intended to facilitate tax avoidance. ${ }^{102}$

Third, OECD Commentaries may come within the scope of application of Article 31, paragraph 3(b) of the VCLT. ${ }^{103}$ According to this provision, for the purpose of the interpretation of a treaty, account shall be taken of "any subsequent practice in the application of the treaty which establishes the agreement of the parties regarding its interpretation". Some tax law scholars exclude the relevance of Article 31, paragraph 3(b) on either of two bases: first, as argued, OECD Commentaries do not amount to practice in the application of any tax treaty; second, because OECD Commentaries are not legally binding, they never establish any "agreement". ${ }^{104}$ Both objections build on a misunderstanding of Article 31, paragraph 3(b).

Article 31, paragraph 3(b) uses the word "application" in a relatively broad sense of the term. ${ }^{105}$ It does not require the use of a treaty rule by a court of law or public authority for the purpose of resolving a concrete legal dispute. Such a flexible stance toward the concept makes a great deal of sense if we recall that the bulk of international law is all about the conduct of states relative to other states and that, typically, a dispute concerning the interpretation and application of international law will never be brought before any domestic judicial authority or, for that matter, before any judicial authority. Consequently, to the extent that judgments of international courts and tribunals can be trusted, practice in the application of a treaty may take a variety of forms, such as letters invoking a treaty provision sent by the authorities of one state to those of another state, ${ }^{106}$ of decisions adopted by an organ of an international organization on the basis of a treaty provision, ${ }^{107}$ of maps accompanying a draft law submitted by a government to parliament for the purpose of ratifica-

102 The Queen v. Garron [2009] TCC 450, paras. 375-376. Similarly, Case 10-02772 Landskatteretten (National Tax Tribunal; Denmark) and Case 2A.239/2005 Bundesgericht (Federal Supreme Court, Switzerland), paras. 3.4.3, 3.4.5.

103 See, similarly, Lang and Brugger (n. 1), pp. 103-104.

104 See e.g. Lang (n. 38), p. 8; Vogel (n. 1), p. 614; Wattel and Marres (n. 1), p. 227.

105 See, similarly, G. Nolte: "Subsequent conduct comes in a great variety of forms". Introductory Report for the ILC Study Group on Treaties over Time, reproduced in Treaties and Subsequent Practice, ed. G. Nolte (2013), p. 169, at p. 190.

106 See e.g. Rights of US Nationals in Morocco (France v. United States), Judgment of 27 August 1952, ICJ Reports 1952, p. 176, at 210211.

107 See e.g. Namibia (n. 88), p. 22 (para. 22). 
tion of a treaty, ${ }^{108}$ of press releases issued by a ministry of affairs explaining the conclusion of a treaty, ${ }^{109}$ and of later treaty instruments including explicit or implicit reference to an earlier treaty. ${ }^{110}$

As for the expression, "agreement", although it obviously implies the meeting of two or more wills, it presupposes no common intention to create law. ${ }^{111}$ Stated differently, a practice may establish an agreement, in the sense of Article 31, paragraph 3(b) of the VCLT, although it does not entail any legal obligation to understand the treaty in any particular way. ${ }^{112}$ If only legally binding interpretative agreements would come within the scope of application of Article 31, paragraph 3(b), then this provision would be rendered largely pointless, because-like all provisions of the VCLT-it applies only insofar as parties to a treaty have not agreed otherwise. ${ }^{113}$

According to the view defended in this essay, to the extent that a common understanding of the parties to a particular tax treaty can be inferred from OECD Commentaries, those Commentaries may come within the scope of application of Article 31, paragraph 3(b). OECD Commentaries are relevant either because they report on the interpretation and application of tax treaties generally or because they themselves form part of a "practice", in the sense of Article 31, paragraph 3(b). Examples of OECD Commentaries being used for the purpose of establishing a subsequent practice in the sense of Article 31, paragraph 3(b) can be found in the case law of many jurisdictions. In the 2010 case, McDermott Eastern Hemisphere, for example, attention focused on the interpretation of the expression "permanent establishment" used in Article 5, paragraph 2 of the Tax Treaty concluded by India and Mau-

108 See e.g. Sovereignty over Pulau Ligitan and Pulau Sipadan (n. 1), p. 656 (paras. 59-61).

109 Maritime Delimitation In the Area Between Greenland and Jan Mayen (Denmark v. Norway), Judgment of 14 June 1993, ICJ Reports 1993, p. 38, at 51 (para. 289).

110 Soering (n. 33), pp. 33-34 (paras. 101 and 103).

111 The requirement is that the understanding comprises all parties to a treaty-not merely some of them. Although less relevant for the interpretation of tax treaties, which are largely bilateral, this observation is exceptionally important when interpreting multilateral treaties. Further on this topic, see U. Linderfalk, Who are "the parties"? Article 31 \$3(c) of the 1969 Vienna Convention, and the "Principle of Systemic Integration" Revisited, Netherlands International Law Review, Vol. 55 (2008), pp. 343-364.

112 See e.g. Heathrow Airport User Charges (n. 27), p. 353 (paras. 6.76.8).

113 Comp the observations made earlier with respect to Article 31, paragraph 2(a). ritius in $1982 .{ }^{114}$ This provision was broadly the same as Article 5, paragraph 3(a) of the UN Model Convention. The Income Tax Appellate Tribunal of Mumbai stressed the unanimity in the OECD Model and UN Model in relevant aspects and justified its conclusion on the content of the term based on the 1992 OECD Commentary. ${ }^{115}$

Fourth and finally, if it is established that a tax treaty was drafted on the basis of an OECD Model Convention, the Commentaries accompanying the Model may form part of "the circumstances of its conclusion", in the sense of Article 32 of the VCLT. This is the way international courts and tribunals have often dealt with instruments adopted prior to the conclusion of a treaty for purposes of its interpretation. ${ }^{116}$ It is also the way some domestic courts have dealt with OECD Commentaries. Consider Thiel, ${ }^{117}$ for example. The case, which was decided by the High Court of Australia in 1990, dealt with tax treatment of profits resulting from the sale of shares under the Treaty concluded between Switzerland and Australia in 1980. This Treaty had been modeled after the 1977 OECD Model Convention. The taxpayer held that all profits were exempt from tax in Australia since they came within the scope of either Article 7, paragraph 1 on business profits or Article 13, paragraph 3 on alienation of property. As it was commonly agreed that the taxpayer did not have a permanent establishment in Australia, the Court considered whether taxpayer's profits could be said to be the profits of an "enterprise" run by a resident of Switzerland, in accordance with Article 7, paragraph 1 . This prompted a closer look at the definition of an "enterprise", in the sense of Article 3, paragraph 1 of the Treaty. Judge Dawson held that the 1977 OECD Commentaries were documents that formed the basis for the conclusion of the Tax Treaty and provided a guide to the current usage of tax treaty terms by the treaty parties. ${ }^{118}$ To remove uncertainties regarding the precise meaning of the Tax Treaty, therefore, he turned to Commentaries to Article

114 Case IT Appeal No. 8084 (Mum.) Income Tax Appellate Tribunal (ITAT), para. 10. Similarly, see Case IT Appeal No. 1532 (Mum.) Income Tax Appellate Tribunal (ITAT), para. 11.

115 For a similar use of the OECD Commentary, see Case RJ 2008/4568 (Spain).

116 See e.g. Navigational and Related Rights (n. 12), pp. 239-240 (paras. 55-56); European Communities-Measures Affecting the Importation of Certain Poultry Products, WT/DS69/AB/R, Report of the WTO Appellate Body, adopted on 13 July 1998, para. 83.

117 Thiel v. Federal Commissioner of Taxation (22 August 1990); Vann (n. 1), p. 150.

118 Dawson stressed that objections were raised in the legal literature against classifying the Commentaries as part of the context, in the sense of Art. 31 of the VCLT, see paras. 9-10 of the Thiel judgment. 
3 and Article 7 of the 1977 Model. ${ }^{119}$ Judge McHugh stated that the Commentaries to the 1977 Model constituted supplementary means of interpretation and, like Judge Dawson, he considered the Commentaries to Articles 7 and 3. In the case of both judgments, the resort to OECD Commentaries seems to be justified, because they classify as part of the circumstances of the conclusion of the Tax Treaty, in the sense of Article 32 of the VCLT. ${ }^{120}$

In each and every case of interpretation of a tax treaty concluded by OECD member states, there is, of course, always the possibility that interpretation bears on Commentaries, to which one or both parties added observations. Depending on the precise provision of the VCLT relied upon by an interpreter when using OECD Commentaries, such observations may or may not be relevant. If a state expressed disagreement with what the Commentaries stated to be the object purpose of an article of the Model, then the observation would seem to prevent interpreters from conferring this same object and purpose on any tax treaty that this state has concluded. An object and purpose conferred on a treaty by one of its parties will never constitute the "object and purpose" of the treaty, in the sense of Article 31, paragraph 1 of the VCLT, if it is not also conferred by the other (or others). Similarly, if, in making an observation, a state expresses disagreement with what a passage of the Commentaries alleges to be the understanding of an article of the Model, the use of this passage would seem to be no longer justified according to Article 31, paragraph 3(b), for it is a requirement of this provision that a subsequent practice establishes the common understanding of the treaty parties. Somewhat the same thing can be said about the use of Commentaries based on Article 32 of the VCLT. If overall Commentaries classify as part of the circumstance of the conclusion of a tax treaty, when an observation implies that a particular passage of those Commentaries no longer establishes the common understanding of the parties to a tax treaty, neither will this passage allow any inferences as to the meaning of the treaty. If, on the other hand, interpreters use OECD Commentaries to determine the ordinary meaning of some tax treaty term, contrary to the other three cases, the observation would not seem to be immediately relevant. If a state expressed disagreement with what the Commentaries stated to be the common understanding of some term used in the Model, despite the observation, it may still be argued that the Commentaries reflect conventional language. At most, the

119 Ibid., para. 11.

120 Vann has held that all five judges approved recourse to the Commentaries under Article 32, see Vann (n. 1), p. 150. observation may raise some doubts as to the accuracy of any such argument.

\subsection{What May Not Work as a Justification of a Use of OECD Commentaries?}

To complete the inquiry that we began in Section 3.3, we wish to comment specifically on a few further suggestions made by tax law scholars as to what may possibly justify the use of OECD Commentaries as interpretative aids. The suggestions are as follows:

- OECD Commentaries may come within the scope of application of Article 31, paragraph 2(b) of the VCLT. $^{121}$

- OECD Commentaries may classify as "relevant rules of international law", in the sense of Article 31, paragraph 3(c). ${ }^{122}$

- OECD Commentaries may help establish the possible "special meaning" of tax treaty terms, in the sense of Article 31, paragraph $4 .{ }^{123}$

- OECD Commentaries may come within the scope of application of Article 32 of the VCLT, whether or not they belong to any of the two means of interpretation explicitly allowed by this provision. ${ }^{124}$

We believe that neither suggestion is very convincing. We will comment on each suggestion in turn.

According to Article 31, paragraph 2(b) of the VCLT, the context of a treaty shall comprise "[a]ny instrument which was made by one or more parties in connexion with the conclusion of the treaty and accepted by the others parties as an instrument related to the treaty". For three reasons, we conclude that OECD Commentaries do not come within the scope of application of this provision. First, an OECD Commentary is not made by any party to a tax treaty. Second, and for the same reason, an OECD Commentary is not made in connection with the conclusion of any tax treaty. Third and finally, if it would typically be difficult to establish that parties to a tax treaty are legally bound by OECD Commentaries because of acquiescence or estoppel, ${ }^{125}$ then it would seem to be equally

121 See e.g. K. van Raad, Interpretatie van Belastingverdragen, MBB 1978/49, quoted in translation by Wattel and Marres (n. 1), p. 226; G. Lindencrona, Dubbelbeskattningsavtalsrätt (1994), cit. Dahlberg (n. 5), p. 152.

122 See e.g. Dahlberg (n. 5), p. 153.

123 See e.g. Ault (n. 1), p. 146 ff; Vogel (n. 1), pp. 614-615.

124 See e.g. Wattel and Marres (n. 1), p. 228.

125 See section 3.2. 
difficult to establish that parties to a tax treaty have $a c$ cepted an OECD Commentary as an instrument related to the treaty. It is apt to compare OECD Commentaries with treaty reservations, ${ }^{126}$ which is the classical example of what comes within the scope of application of Article 31, paragraph 2(b). It is no mere coincidence that Article 31, paragraph 2(b) uses the term "instrument", because reservations are typically included in the instrument sent by states to depositories upon the ratification or accession of a treaty. As stated in Article 20, paragraph 5 of the VCLT, the acceptance of a reservation is to be presumed:

[U]nless the treaty otherwise provides, a reservation is considered to have been accepted by a State if it shall have raised no objection to the reservation by the end of a period of twelve months after it was notified of the reservation or by the date on which it expressed its consent to be bound by the treaty, whichever is later.

No similar presumption exists that can be applied to OECD Commentaries.

According to Article 31, paragraph 3(c) of the VCLT, for the purpose of the interpretation of a treaty, account shall be taken of "[a]ny relevant rules of international law applicable in the relations between the parties". The reason for our finding that OECD Commentaries do not come within the scope of application of this provision lies in its justification. Article 31, paragraph 3(c) assumes the use of a particular communicative assumption: the assumption that parties to the interpreted treaty arranged so that it does not derogate from any other international legal norm applicable in the relationship between them. ${ }^{127}$ Terms such as "applicable" and "derogate", in turn, strongly indicate that only rules derived from one of the recognized sources of international law can come within the scope of application of Article 31, paragraph 3(c). ${ }^{128}$ This excludes OECD Commentaries.

According to Article 31, paragraph 4 of the VCLT, "[a] special meaning shall be given to a term if it is established

126 Treaty reservations are a potent means of interpretation. If, for example, Bahrain makes a reservation to Article 27, paragraph 3 of the 1961 Vienna Convention on Diplomatic Relations, reserving "its right to open the diplomatic bag if there are serious grounds for presuming that it contains articles the import or export of which is prohibited by law", then this indicates at least as far as concerns Bahrain's understanding of Article 27, paragraph 3, that the provision would not otherwise confer this right.

127 See e.g. Ijzeren Rijn (n. 36), at pp. 72-73 (para. 79).

128 One cannot derogate from a rule that does not entail obligations under international law. As to the recognized sources of international law, comp Art. 38, para. 1(a), (b), and (c) of the Statute of the International Court of Justice. that the parties so intended". There is a clear relationship between the special meaning referred to in this provision and the ordinary meaning referred to in Article 31, paragraph 1. In the terminology of the VCLT, if a meaning is not ordinary it will classify as special, and if a meaning is not special it will classify as ordinary. A "special meaning" means simply any meaning of a term that does not follow merely from conventional language. ${ }^{129}$ If we recall this definition, the true contents of Article 31, paragraph 4 appear more clearly. What Article 31, paragraph 4 establishes is no more than a burden of proof: If an interpreter were to argue that the ordinary meaning of a treaty does not correspond to the communicative intention of the parties, then it would rest upon the interpreter to justify this suggestion. As always, when the communicative intention of the parties to a treaty needs establishing, justification will have to be found in Articles 31 and 32 of the VCLT. The interpreter has to show (i) that the ordinary meaning is ambiguous or obscure or is manifestly absurd or unreasonable and (ii) that the use of some other means of interpretation than conventional language leads to a different result-either because it implies a preference for one of the two possible ordinary meanings or because it implies the adoption of a meaning that is entirely outside the scope of what the ordinary meaning allows. Consequently, we are skeptical about the suggestion that OECD Commentaries may help to establish the "special meaning" of tax treaty terms. The suggestion is correct, of course, if it means that OECD Commentaries may be used to inform the interpretation of tax treaties in cases in which the ordinary meaning is ambiguous or obscure, or manifestly absurd or unreasonable. This is the fundamental assumption underlying what we concluded in Section 3.2: that OECD Commentaries may be used to determine the object and purpose of a tax treaty; that they may form part of the circumstances of the conclusion of a tax treaty; and, again, that they may come within the scope of application of Article 31, paragraph 3(b) of the VCLT. The suggestion is clearly incorrect,

129 Comp Draft Article 71, as provisionally adopted by the ILC in 1964:

\section{"Article 71. Terms having a special meaning}

Notwithstanding the provisions of paragraph 1 of article 69, a meaning other than its ordinary meaning may be given to a term if it is established conclusively that the parties intended the term to have that special meaning."

Draft Articles on the Law of Treaties, Report of the International Law Commission covering the work of its sixteenth session, ILC Yrbk, 1964, Vol. 2, p. 174, at 199. 
however, if it means that Article 31, paragraph 4, in and of itself, may provide justification for using OECD Commentaries. Establishing only the burden of proof, Article 31, paragraph 4 remains dependent on the existence of rules of interpretation proper. Those are the rules that may provide justification for using OECD Commentaries, and not Article 31, paragraph 4.

The suggestion that OECD Commentaries may come within the scope of application of Article 32 of the VCLT for the purpose of interpreting a tax treaty, whether or not they are part of "the preparatory work of the treaty or the circumstances of its conclusion", builds on a misunderstanding of Article 32. Certainly, by explicitly allowing the use of preparatory work and the circumstances of the conclusion of a treaty, Article 32 does not exhaust the concept of supplementary means of interpretation. This is evident from its wording. According to Article 32, "[r]ecourse may be had to supplementary means of interpretation, including the preparatory work of the treaty or the circumstances of its conclusion". ${ }^{130}$ At the same time, not everything can be used to aid the interpretation of a treaty and then be classified as a "supplementary means of interpretation". "[S]upplementary means of interpretation" assumes reference to the existing customary international law. ${ }^{131}$ In order for something to classify as a supplementary means of interpretation, separate from the preparatory work of a treaty and the circumstances of its conclusion, it has to be recognized as such in the practice of states and international judiciaries. In the case of OECD Commentaries, there is nothing close to such a practice.

\section{Making choices: taking an ambulatory or a static approach}

\subsection{Perennial Questions}

As observed in Section 2 of this essay, any act of treaty interpretation performed in conformity with Articles 31-33 of the VCLT remains dependent upon the use of a communicative assumption. A treaty can be understood only on the assumption that the parties to the treaty acted rationally-that they acted in conformity with one or several communicative standards. The interpreter may assume, for example, that the parties to the treaty arranged so that a consistent meaning could be conferred on all

130 Italics are added.

131 Linderfalk (n. 30), pp. 238-239. words and lexicalized phrases used throughout the treaty or so that no norm expressed in the treaty logically would contradict any other or again so that no part of the treaty comes out as redundant. ${ }^{132}$ For the analysis of Articles 3133 of the VCLT, this observation is key. If treaty interpretation remains consistently dependent on the use of communicative assumptions, then the relevant international law can be described as rules of interpretation proper. By a rule of interpretation proper, lawyers usually mean a rule stated in a particular form: "if, in the interpretation of a treaty, a state of affairs of a particular kind $\mathrm{P}$ obtains, then the treaty shall be interpreted in a particular manner $\mathrm{Q}^{\prime}{ }^{133}$ In the case of the three communicative standards referred to earlier in this paragraph, for example, the relevant rules of interpretation would read something along the following lines:

- If in one of the two possible ordinary meanings of a treaty provision, the treaty entails a logical contradiction, whereas in the other ordinary meaning it does not, then the latter meaning shall be adopted.

- If one of the two possible ordinary meanings of a treaty provision makes part of the treaty redundant, whereas the other ordinary meaning does not, then the latter meaning shall be adopted.

- If one of the two possible ordinary meanings of a treaty provision implies that a word or a lexicalized phrase has been used inconsistently throughout the treaty, whereas the other ordinary meaning does not, then the latter meaning shall be adopted.

As Section 3 concluded, the four rules of interpretation relevant for consideration of the static/ambulatoryapproaches debate are the following. For purposes of easy reference, henceforth in this essay, we will denote them as Rules (1), (2), (3), and (4), respectively:

Rule (1) If a treaty uses elements of conventional language (such as words, grammatical structures, or pragmatic features), the treaty shall be understood in accordance with the rules of that language.

Rule (2) If one of the two possible ordinary meanings of a treaty helps attain its object and purpose better than the other, then the former meaning shall be adopted.

Rule (3) If one of the two possible ordinary meanings of a treaty accords with the common understanding of the parties to the treaty as established by

132 See Section 2.2.

133 See e.g. J. Wróblewski, The Judicial Application of Law (1992), pp. $96 \mathrm{ff}$. 
the way they apply it, whereas the other meaning does not, then the former meaning shall be adopted.

Rule (4) If the circumstances of the conclusion of a treaty indicate a common understanding on the part of the negotiating parties of a particular term of the treaty, then this term shall be interpreted accordingly.

This statement of the relevant international law helps explain its inconclusive nature. The fact remains that in applying most, if not all, rules of interpretation, interpreters exercise discretion. ${ }^{134}$ Most important for the purpose of this essay:

- In the application of Rule (1), interpreters are left to decide whether to operate based on the language in use at the time of the conclusion of the treaty or the language in use at the time of interpretation.

- In the application of Rule (2), interpreters are left to decide whether to operate based on the object and purpose conferred on a treaty at the time of its conclusion or the object and purpose conferred at the time of interpretation.

- In the application of Rule (3), interpreters are left to decide whether "the common understanding of the parties" means the understanding that existed at the time of the conclusion of a treaty or the understanding that exists at the time of interpretation.

For the purpose of interpreting a tax treaty, if Rule (4) would seem naturally to limit the use of OECD Commentaries to those that existed at the time of its conclusion, ${ }^{135}$ this same conclusion does not apply to all rules of interpretation. To the extent of Rules (1), (2), and (3), later adopted Commentaries may also be used.

This analysis is bound to raise questions among tax law scholars, for two reasons. First, as a great number of scholars would seem to see it, there is a paradox in concluding that a changed OECD Commentary may be relevant for the interpretation of an earlier tax treaty, while still assuming that it is the purpose of the entire interpre-

134 See Linderfalk (n. 30), Ch 12.

135 This is not to say that Rule (4) necessarily limits the use of OECD Commentaries to a version that had been formally published at the time of the conclusion of a tax treaty. As argued by Vann, if the CFA had already started working on a new revised version of the Commentaries, and the parties to a tax treaty were well acquainted with and even actively participated in this work, then this work may well have influenced the drafting of the treaty, even though at the time of its conclusion, the revised Commentaries had still not been formally published. Vann (n. 1), pp. 152-155. We are inclined to agree. tation process to establish the communicative intention of the parties to that treaty. How can an OECD Commentary ever help interpreters gain insights into the communicative intention of the parties to a tax treaty, if this Commentary did not even exist when the treaty was concluded? ${ }^{136}$ As we will argue in Section 4.2, this objection overlooks the referring possibilities provided by many languages.

Second, tax law scholars will ask the question we raised at the beginning of this essay: To the extent that the use of OECD Commentaries can be justified based on international law, should a static or an ambulatory approach be taken? ${ }^{137}$ As we concluded earlier in Section 4.1, no definitive answer to this question can possibly be found in the rules of interpretation laid down in the VCLT, and those rules only. When an OECD Commentary was adopted subsequent to the conclusion of an interpreted tax treaty, as far as Rules (1), (2), and (3) are concerned, interpreters may decide freely whether or not to use the Commentary. This is not to say that in making this decision, interpreters exercise an unlimited discretion. As we will argue, that would be a misunderstanding of the law laid down in the VCLT. According to this law, the choice of interpreters still remains subject to the application of the principle of good faith. ${ }^{138}$ This typically implies that one but not both of the static and the ambulatory approaches will be correct under international law. We will argue this proposition in Section 4.3.

\subsection{Party Intention and the Concept of Reference}

As repeatedly stated throughout this essay, Articles 31-33 of the VCLT builds upon the idea of a treaty as a vehicle used by treaty parties to convey their communicative intention to readers. To ensure successful communication, parties to a treaty exploit the referring possibilities of the treaty language or languages. Reference, as this term is generally defined in linguistics, ${ }^{139}$ is the relationship held

136 See e.g. Klaus Vogel on Double Taxation Conventions (n. 5), Introduction, paras. 82(a) and (b); Lang, Introduction to the Law of Double Taxation Convention, IBFD (2010), para. 94; Vogel, 2000 (n. 1), p. 615; Ward (n. 1), p. 101; Lang and Brugger (n. 1), p. 102.

137 See e.g. Vogel, 2000 (n. 1), p. 615; Wattel and Marres (n. 1); Vann (n. 1); Ault (n. 1); Lang and Brugger (n. 1).

138 See U. Linderfalk, The Concept of Treaty Abuse: On the Exercise of Legal Discretion (November 17, 2014). Available at SSRN: http://ssrn. com/adstract $=$.

139 It should be noted that in linguistics, the usage of this term is not fully consistent. 
between, on the one hand, an expression, and, on the other hand, what the expression stands for in the world at the occasion of its utterance-what linguistics would normally call the referent. ${ }^{140}$ The referring possibilities of a language turn on the extension to which its conventions help utterers (i.e. writers and speakers) make addressees (i.e. readers and listeners) aware of the existence of an intended relationship between an expression and a referent.

An expression used by a writer of a text for the purpose of reference is a referring expression. ${ }^{141}$ Referring expressions can be described as members of different categories. ${ }^{142}$ First, a distinction will have to be made between those expressions that refer to a single entity and those that refer to a group of entities. Drawing on the terminology used by linguistics, henceforth in this essay, expressions referring to a single entity will be termed singular referring expressions. Expressions referring to a group of entities will be termed general referring expressions. ${ }^{143}$ Take, for example, Article 2 of the Special Agreement concluded between Niger and Benin on 15 June 2001. The Agreement confirms the decision of the two states to submit to a Chamber of the International Court of Justice a dispute concerning the delimitation of the boundary between them:

The Court is requested to:

(a) determine the course of the boundary between the Republic of Benin and the Republic of Niger in the sector of the River Niger;

(b) specify which State owns each of the islands in the said river, and in particular Lété Island;

(c) determine the course of the boundary between the two States in the sector of the River Mekrou. ${ }^{144}$

The referent of the expression "The Court" (chapeau) is the International Court of Justice; the referent of the expression "State" (lit. b) is either Benin or Niger. Both are singular referring expressions. The referent of the expression "the two States" (lit. c) is Benin and Niger; the referent of the expression "the islands" (lit. b) is the islands in the River Niger. Both are general referring expressions.

Second, in categorizing referring expressions, we have to accommodate for the fact that many expressions do not refer to single entities or groups of entities, but only to classes of entities. Take, for example, Article VI of

140 See e.g. J. Lyons, Semantics (1977), p. 177.

141 Ibid.

142 Ibid., pp. 177-197.

143 Comp ibid., p. 178.

144 For the full text of the Agreement, see Frontier Dispute (Benin/Niger), Judgment of 12 July 2005, ICJ Reports 2005, p. 90, at 95; italics are added. the Treaty on Territorial Limits concluded between Costa Rica and Nicaragua, on 15 April 1858. Consider especially the two (italicized) expressions "The vessels" and "commerce":

\begin{abstract}
The Republic of Nicaragua shall have exclusively the dominion and sovereign jurisdiction over the waters of the San Juan river from its origin in the Lake to its mouth in the Atlantic; but the Republic of Costa Rica shall have the perpetual right of free navigation on the said waters, between the said mouth and the point, three English miles distant from Castillo Viejo, said navigation being for the purposes of commerce either with Nicaragua or with the interior of Costa Rica, through the San Carlos river, the Sarapiquí, or any other way proceeding from the portion of the bank of the San Juan river, which is hereby declared to belong to Costa Rica. The vessels of both countries shall have the power to land indiscriminately on either side of the river at the portion thereof where the navigation is common; and no charges of any kind, or duties, shall be collected unless when levied by mutual consent of both Governments. ${ }^{145}$
\end{abstract}

Grammatically, "The vessels" is an expression articulated in the definite plural. Nevertheless, as is evident from the immediate context, "The vessels" is not a generally referring expression; it does not refer to any group of vessels. It refers to the class, or genus, of vessels, as defined by the institutional practice of some specific community of language users-in this case, possibly users of the English language in general. ${ }^{146}$ Similarly, "commerce", although it is articulated in the indefinite singular, is not a singular referring expression; it does not refer to any single activity, but to the class of activity that English-speaking people call commerce. In linguistics, expressions such as "The vessels" and "commerce" are termed generic referring expressions. ${ }^{147}$ We will use this same terminology in this essay.

As the examples of the 1858 Treaty on Territorial Limits clearly demonstrate, many words and phrases of the

145 For the full text of the Treaty, see Application instituting proceedings, Navigational and Related Rights (n. 19), available through the webpage of the Court: http://www.icj-cij.org, pp. 22, 24; italics are added.

146 Note that a class may be defined by institutional practices other than the conventions of a common language. Examples include the practice of UN organs ("human rights"), the teaching of natural science ("the quality of the water in the Danube"), and the moral standards in European countries ("morals"). See, respectively, Art. 55 of the Charter of the United Nations; Art. 15 of the 1972 Treaty between Hungary and Czechoslovakia Concerning the Construction and Operation of the Gabčíkovo-Nagymaros System of Locks; and Art. 8 of the European Convention on the Protection of Human Rights and Fundamental Freedoms.

147 See e.g. Lyons (n. 140), pp. 193-197. 
English language (and, of course, many other languages) are ambiguous, in the sense that they allow utterers to use them for different referring purposes. For example, whereas a term such as "The vessels" can be used as a general referring expression, it can also be used to refer generically. In a process of understanding, contexts of utterance typically help readers or listeners to overcome this difficulty. Most important, they do so because there is a significant general difference between generically referring expressions, on the one hand, and singular and general referring expressions, on the other: Singular and general referring expressions express time-bound propositions; generically referring expressions do not. ${ }^{148}$ In Article 2 of the 2001 Special Agreement between Niger and Benin, for example, the existence of the referent of "The Court" pertains to the point in time when, according to Article 40 of the Statute of the International Court of Justice, the Court is notified of the Agreement. The existence of "the islands" would seem to pertain to the point in time of the utterance. In Article VI of the 1858 Treaty on Territorial Limits, on the other hand, it would appear somewhat irrelevant to ask which day and month, or even which year, "[t]he vessels of both countries shall have the power to land indiscriminately on either side of the river..." . The existence of the referent of "The vessels" does not pertain to any particular moment or time span. In a way, we can say that the existence of the referent of "The vessels" is outside time altogether. ${ }^{149}$

This observation prompts yet another key distinction. Among generically referring expressions, we must distinguish between those with stable referents over time and those with referents that can possibly change or develop. ${ }^{150}$ Take, for example, Article VI of the 1858 Treaty on Territorial Limits. If "commerce" is a generically referring expression, then the referent of this expression is a class of activities, the existence of which does not pertain to any particular moment in time or to any particular time span. The timelessness of the referent can be explained in two ways. ${ }^{151}$ According to one of these explanations, Costa Rica and Nicaragua assumed in 1858 that, for as long as the Treaty on Territorial Limits was to be in force, the class called "commerce" would remain exactly

\footnotetext{
148 Ibid., p. 194.

149 Ibid., p. 680.

150 See U. Linderfalk, Doing the Right Thing for the Right Reason: Why Dynamic or Static Approaches Should Be Taken in the Interpretation of Treaties, International Community Law Review, Vol. 10 (2008), pp. 109-141.

151 It should be recalled that the reference of an expression remains a product of the intention of its utterer.
}

the same: If, in 1858, English-speaking people referred to commerce as the purchase and sale of physical goods, but not as services, such as passenger transport, they would continue to use the term similarly throughout the life span of the Treaty. According to the other explanation, Costa Rica and Nicaragua assumed in 1858 that, during the life span of the Treaty on Territorial Limits, the class called "commerce" would possibly change or develop: If in 1858, English-speaking people referred to commerce as the purchase and sale of physical goods but not as services of any kind, then at some point during the life span of the Treaty they might start to use the term differently. In the former case, the referent of "commerce" would have been defined by the usage of this term among English-speaking people in 1858. In the latter case, the referent of "commerce" would have been defined by the use of this term among English-speaking people at each and every moment. We refer to those two categories of generically referring expressions as static and dynamic, respectively.

This excursion into the theory of reference helps to answer the perennial question underlying much of the static/ambulatory-approaches debate: How can an OECD Commentary ever help interpreters gain insights into the communicative intention of the parties to a tax treaty if this Commentary did not even exist when the treaty was concluded? The obvious answer to this question lies in the concept of reference. As already explained, to convey their communicative intention to readers, treaty parties exploit the fact that according to the conventions of languages such as English, certain words and combinations of words can be used for the purpose of reference. When readers succeed in identifying the intended referent of a treaty expression, it is partly because of those language conventions and partly because of the context of the expression. To illustrate, once again take Article 2 of the 2001 Special Agreement between Niger and Benin. If readers of this treaty succeed in identifying Benin and Niger as the referent of the expression "the two States", it is partly because the English language provides utterers with the possibility of using this combination of words to refer generally (to a group of two states) and partly because, as they have come to learn, Benin and Niger are the parties to the Agreement.

Now, as indicated earlier, the identification of the referent of a generically referring expression assumes a specific type of context. In order to be able to identify the referent of an expression such as "commerce" in the 1858 Treaty on Territorial Limits between Costa Rica and Nicaragua, readers must first understand that a class of activities rather than any single activity is being referred to. Second, readers must grasp the assumed institutional prac- 
tice, by which the class is to be defined. If it is accepted that "commerce" is a dynamic generically referring expression and that, consequently, the assumed definition of this expression depends on a developing institutional practice and not on an institutional practice that already existed in 1858, then of course, if a document of some kind could help readers gain insight into that practice, then this document will be relevant for the interpretation of this expression. Similarly, if it is established that a tax treaty uses a dynamic generically referring expression, a changed OECD Commentary may be equally relevant. To the extent that the Commentary helps to identify the relevant institutional practice-tax treaty language, or simply the practice of tax treaty law, for instance-consequently, there is nothing strange or paradoxical about using it for the purpose of establishing the communicative intention of the treaty parties.

\subsection{Making Choices in Good Faith}

In discussing the possibility of accounting for changed OECD Commentaries for the purpose of interpreting earlier tax treaties, tax law scholars typically assume one or another system of categorizing such Commentaries. ${ }^{152}$ The implication is that once interpreters have identified some given OECD Commentaries as a member of a particular category, they will be able to tell immediately if those Commentaries are relevant for interpretation. As a matter of general law, for reasons already indicated in Section 4.2, such suggestions seem difficult to defend. The more sensible approach is to address choices between a static and an ambulatory approach on a case-by-case basis only, as a matter of good faith.

According to Article 26 of the VCLT, "[e]very treaty in force is binding upon the parties to it and must be performed by them in good faith". Good faith is a general principle of international law. ${ }^{153}$ As argued extensively elsewhere, it stands for the idea that international law is a purposive endeavor. ${ }^{154}$ To negotiate in good faith, for example, means to conduct negotiations with a view to arriving at an agreement or some other positive result. ${ }^{155}$ To fulfill in good faith obligations ensuing from a unilateral

152 See above, Section 1.

153 See e.g. Bin Cheng, General Principles of Law as Applied by International Courts and Tribunals (1953).

154 See Linderfalk (n. 138).

155 See e.g. North Sea Continental Shelf (Federal Republic of Germany/Denmark; Federal Republic of Germany/Netherlands), Judgment of 20 February 1969, ICJ Report 1969, p. 3, at 46-47 (para. 85). declaration accepting the compulsory jurisdiction of the International Court of Justice (ICJ) means to behave so as to allow other states the possibility of placing confidence in the acceptance. ${ }^{156}$ Similarly, to perform a treaty in good faith means to perform the treaty for a purpose. ${ }^{157}$ Accepting this definition and applying it to the particular issue of treaty interpretation, the principle of good faith would seem to set a limit on any discretion exercised by an interpreter under the law laid down in Articles 31-33 of the VCLT. ${ }^{158}$ If the exercise of the discretion conferred on interpreters under Articles 31-33 were to be completely free, that would be to accept that this discretion will sometimes be exercised either unreasonably (i.e. for any purpose) or arbitrarily (i.e. for no purpose at all). The principle of good faith would seem to suggest otherwise. If it is the purpose of treaty interpretation to establish the communicative intention of treaty parties, it would seem only natural that interpreters be guided by this same idea throughout the entire process of interpretation, even in those cases in which the settlement of an issue is left to their discretion.

Consequently, in the exercise of any discretion conferred under Articles 31-33 of the VCLT, interpreters should continue the search for the communicative intention of treaty parties. As we see it, there is simply no other way for interpreters to comply with the principle of good faith. To illustrate the further implications of this requirement, consider the Dispute between Costa Rica and Nicaragua regarding Navigational and Related Rights. ${ }^{159}$ In this case, the ICJ was asked to give an opinion on the scope of application of a Treaty of Territorial Limits concluded by the two disputing parties in 1858. The Treaty established Nicaragua's dominion and sovereign jurisdiction over the waters of the San José River, while simultaneously affirming Costa Rica's right to navigate the lower course of the river for purposes of commerce ("con objetos de comercio"). Nicaragua argued that the ordinary meaning of "commerce" excluded all services, such as passenger transport, "because in 1858 the word "commerce" necessarily meant trade in goods and did not extend to services, the inclusion of services being a very recent development". ${ }^{160}$ As pointed out in Sections 4.1 of this essay, Article 31, paragraph 1 of the VCLT-Rule (1), to be

156 See Military and Paramilitary Activities in and Against Nicaragua (Nicaragua $v$ United States), Jurisdiction, Judgment of 26 November 1984, ICJ Reports 1984, p. 392, at 414-415 (para. 51).

157 Linderfalk (n. 138).

158 Ibid.

159 Navigational and Related Rights (n. 12).

160 Ibid., pp. 240-241 (para. 58). 
specific-leaves the definition of "the ordinary meaning" to the discretion of interpreters. Addressing the situation, confronting it, the ICJ affirmed that as a matter of principle:

[T] he terms used in a treaty must be interpreted in light of what is determined to have been the parties' common intention, which is, by definition, contemporaneous with the treaty's conclusion. ${ }^{161}$

As it immediately added, however, it did not necessarily follow that no account should ever be taken of the meaning of a treaty at the time of interpretation:

[T]here are situations in which the parties' intent upon conclusion of the treaty was, or may be presumed to have been, to give the terms used-or some of them-a meaning or content capable of evolving, not one fixed once and for all, so as to make allowance for, among other things, developments in international law. In such instances it is indeed in order to respect the parties' common intention at the time the treaty was concluded, not to depart from it, that account should be taken of the meaning acquired by the terms in question upon each occasion on which the treaty is to be applied. ${ }^{162}$

The Court decided that in the application of Rule (1) to the Treaty of Territorial Limits, they would have to take an ambulatory approach and operate on the basis of the language in use at the time of interpretation. If this decision is subject to the principle of good faith, justification would have to be given through the answer to a specific question: What convincing reasons are there to assume that in 1858, Costa Rica and Nicaragua intended the meaning of "commerce" to be defined by the usage of English-speaking people at each and every moment of application? The Court seemed highly aware of the onus placed upon it, when pointing out that in 1858 , it was the intention of the parties that the Treaty of Territorial Limits would remain in force for a very long time:

[W] here the parties have used generic terms in a treaty, the parties necessarily having been aware that the meaning of the terms was likely to evolve over time, and where the treaty has been entered into for a very long period or is "of continuing duration", the parties must be presumed, as a general rule, to have intended those terms to have an evolving meaning. ${ }^{163}$

It remains debatable, of course, whether this argument is convincing in and of itself; but let us leave this discussion for other occasions. The interesting thing to observe is that

161 Ibid., p. 242 (para. 63).

162 Ibid., p. 242 (para. 64).

163 Ibid., pp. 243 (para. 66). the ICJ was not content with justifying its choice of the "evolving meaning" of "commerce" by merely referring to the discretion left to it under Article 31, paragraph 1 of the VCLT. In contrast, it took great pains to construct it as the result of the assumed common intention of the treaty parties.

\subsection{How to Justify Choices Between a Static and an Ambulatory Approach}

We have now reached the point where we can start tying strings together. As stated in Section 4.1, Rules (1), (2), and (3), leave it to interpreters to decide whether, in using OECD Commentaries, they should adopt a static or an ambulatory approach. Our suggestion is that this choice be made following a two-stage procedure. First, interpreters would have to establish whether the object of interpretation is a singular, general, or generic referring expression. Assuming that the choice concerns a particular term (M) of a particular treaty (T), the question to be addressed is the following:

Is there reason to assume that in concluding $\mathrm{T}$, the treaty parties used $\mathrm{M}$ as a generic referring expression?

If this question is answered in the negative, a static approach should naturally be taken. If, on the other hand, the question is answered in the positive, interpreters enter the second stage of the procedure and would then have to establish whether $M$ is a static or a dynamic generic referring expression. Assuming that the referent of $M$ is a particular class (C), depending on whether the choice between a static and an ambulatory approach concerns the application of Rules (1), (2), or (3), the question addressed is one of three:

1. Is there reason to assume that in concluding $\mathrm{T}$, the treaty parties intended $\mathrm{C}$ to be defined by the language conventions existing at whatever time $\mathrm{M}$ is interpreted?

2. Is there reason to assume that in concluding $\mathrm{T}$, the treaty parties intended $\mathrm{C}$ to be defined by the object and purpose conferred on the treaty at whatever time $\mathrm{M}$ is interpreted?

3. Is there reason to assume that in concluding $\mathrm{T}$, the treaty parties intended $\mathrm{C}$ to be defined by the understanding of the parties at whatever time $\mathrm{M}$ is interpreted?

If questions are answered in the negative, a static approach should naturally be taken. If, on the other hand, 
questions are answered in the positive, this suggests an ambulatory approach.

For any rational choice between a static and an ambulatory approach to the use of OECD Commentaries, based on what we know about the practice of international law generally, the focus will inevitably be on these three questions. We will now give suggestions on how those questions could possibly be addressed. Given the purpose of the present essay as stated in Section 1, we have decided to abstain from suggesting anything that bears directly on the concrete facts of any particular dispute. We will limit ourselves to indicating factors that we consider generally relevant. It should be noted that no rational choice between a static and an ambulatory approach can ever be made solely on the basis of any one of the suggested factors. As so often occurs with practical reasoning, choices have to be made on the basis of an overall assessment, considering all relevant factors. Relevant general factors include the following four.

\section{The purpose of the treaty or single treaty provision interpreted}

The object and purpose of a treaty operate as an indicator of the intention of treaty parties in the application of several other provisions of the VCLT than Article 31. According to Article 20, for example, although a treaty does not explicitly require the unanimous subsequent acceptance of reservations, such a requirement shall be assumed if it appears from the object and purpose of the treaty that the application of the treaty in its entirety among all the parties is an essential condition of the consent of each to be bound. According to Article 41, although a treaty does not explicitly prohibit certain parties from agreeing to modify the treaty as between themselves, such a prohibition shall be assumed insofar as it concerns modifications incompatible with the effective execution of the object and purpose of the treaty as a whole. If we accept that the object and purpose of a treaty can be used to establish the referring intention of treaty parties as well, it would cohere nicely with an overall reading of the VCLT. It would also explain the prevailing practice of international judiciaries. Notably, in the interpretation of international boundary agreements, international courts and tribunals have been relatively consistent applying Rules (1), (2), and (3) based on a static rather than an ambulatory approach. ${ }^{164}$ Assum-

164 Comp e.g. Kasikili/Sedudu Island (n. 31); Guinea-GuineaBissau Maritime Delimitation (n. 26). ing that it is the primary purpose of such agreements to fix a boundary, arguably, the emphasis of treaty parties will be on foreseeability and the creation of a stable legal relationship rather than anything else. Stated more specifically, the mere purpose of a boundary treaty would seem to be reason to assume that parties intended generic referring expressions to be defined by the relevant institutional practices existing at the time of conclusion, rather than at whatever time the treaty is interpreted. ${ }^{165}$

The basic idea justifying the conclusion of double taxation conventions is to eliminate double taxation, because of its harmful effects on cross-border economic activities, such as trade in goods and services, and the movement of capital and people between countries. This elimination is thought to be necessary to create tax conditions for economic activities with international ramifications that are not less favorable than those for domestic economic activities. The general assumption underlying tax treaties based on the OECD Model, therefore, is that an item of income is subject to the normal taxing regime in either of the states. ${ }^{166}$ Ideally, tax treaties create tax conditions, which neither encourage nor discourage cross-border economic activities, as compared to domestic economic activities, so as to develop the economic relations between countries. Consequently, in establishing the referring intentions of the parties to a tax treaty, the relevant question for an interpreter to ask should be this: What is the way to apply the treaty to facilitate a globalized economy? It is not self-evident, as sometimes argued, that a globalized economy is best achieved by creating static and easily foreseeable conditions for taxpayers. With a progressively changing economic reality, involving new business models, the development of new technologies, changes in the way cross, border activities are undertaken, the increasing level of sophistication of tax avoidance strategies, arguably, the focus of tax treaty parties will be on issues of adaptation. To paraphrase the European Court of $\mathrm{Hu}$ -

$\mathbf{1 6 5}$ This should not be understood to invite overgeneralization. As we readily admit, treaties have often not only one, but several purposes. Consequently, within the framework of a single treaty instrument, the different purposes of particular provisions may sometimes suggest that interpreters take different approaches, depending on the provision being interpreted. This could explain the finding of the ICJ in Navigational and Related Rights. The purpose of the Treaty of Territorial Limits between Costa Rica and Nicaragua did not exist merely to end all territorial differences, but also to promote trade relations for the mutual benefits of the two nations. Comp especially the preamble to the treaty and Art. V.

166 S. van Weeghel, The Improper Use of Tax Treaties-With Particular Reference to the Netherlands and the United States (1998), pp. 3334. 
man Rights in Stafford v. UK: A failure to maintain an ambulatory approach would create the risk of rendering tax treaties a bar to economic development and growth. ${ }^{167}$

\section{The intended life span of the treaty}

In La Bretagne Arbitration, ${ }^{168}$ the Arbitration Tribunal considered the following provision of a Fishing Agreement concluded between France and Canada in 1972:

1. Canadian fishery regulations shall be applied without discrimination in fact or in law to the French fishing vessels covered by Articles 3 and 4 [i.e., among others, French trawlers registered in St. Pierre et Miquelon], including regulations concerning the dimensions of vessels authorized to fish less than 12 miles from the Atlantic coast of Canada. ${ }^{169}$

The question was whether the Agreement conferred on Canada a regulatory power that made the right of French vessels to fish conditional on the granting of a license, and if so, whether, in the application of a licensing system, Canadian authorities had the competence to stipulate the terms of fishing operations concerning not only fishing as such, but also the processing of the catch on board fishing vessels. As the Tribunal concluded, the meaning of "fishery regulations" had to be determined in the light of fishery regulations adopted by coastal states generally since 1972, for two reasons. First, a generic referring expression was involved:

[T] he authors of the 1972 Agreement used the term "fishery regulations" as a generic formula covering all the rules applicable to fishing activities, while the reference to the dimensions of the vessels appears to suggest that a particular purpose was thereby intended, namely the limitation of these vessels' fishing capacity. ${ }^{170}$

Second, the relevant expression "was embodied in an agreement concluded for an unlimited duration". As the Tribunal explained, all things considered, "it is hardly conceivable that the Parties would have thought to give it [i.e. the expression] an invariable content" ${ }^{171}$

167 ECHR 2002-IV. Compare the original text: " A failure by the Court to maintain a dynamic and evolutive approach would risk rendering it a bar to reform or improvement" (para. 68).

168 Dispute Concerning Filleting within the Gulf of St Lawrence ("La Bretagne") (Canada/France), Award of 17 July 1986, International Law Reports, Vol. 82, p. 591.

169 Ibid., p. 601.

170 Ibid., pp. 619-620 (para. 37).

171 Ibid.
If this same kind of reasoning is applied to the interpretation of tax treaties, it would seem important that tax treaties are generally expected to remain in force for some 10 to 20 years only. This is certainly not a long time compared, for example, to the duration of most boundary agreements. The question is whether time is the crucial factor. We suggest it is not. As we would like to think, the length of the intended life span of a treaty will inevitably be relative to the expected pace of change of the relevant institutional practice. In the La Bretagne Arbitration, for example, if the Tribunal considered the intended life span of the 1972 Fishing Agreement to be an important factor, as we interpret the Award, this was not only because of the time wise life expectancy of the Agreement, but also because-as the parties to the Agreement were surely aware-states amend their fishing regulations relatively frequently. Similarly, in Gabčíkovo-Nagymaros Project, ${ }^{172}$ when the International Court of Justice commented on the various suggested interpretations of Article 15, paragraph 1 of the 1977 Treaty between Czechoslovakia and Hungary, it was taken for granted that the meaning of "the quality of the water in the Danube" turned partly on the development of environmental knowledge. It did so primarily because Czechoslovakia and Hungary had themselves, already in this same article, recognized the potential necessity of incorporating any such development by frequently updating the Joint Contractual Plan. ${ }^{173}$ Article 15, paragraph 1 reads as follows:

The Contracting Parties shall ensure, by the means specified in the joint contractual plan, that the quality of the water in the Danube is not impaired as a result of the construction and operation of the System of Locks.

In the work of the OECD, the current practice is to update Commentaries on Model Double Taxation Conventions in intervals of two to three years. Consequently, since 1992, Commentaries have been amended in 1994, 1995, 1997, 2000, 2003, 2006, 2008, 2010 and 2014. Considering thisaccepting that the length of the intended life span of a tax treaty is not simply a matter of counting years-the 10- to 20-year duration of tax treaties would still seem to suggest that parties intend generic referring expressions to be defined with an eye to the future rather than the time of conclusion.

172 Gabčíkovo-Nagymaros Project (Hungary/Slovakia), Judgment of 25 September 1997, ICJ Reports 1997, p. 7.

173 See ibid., pp. 67-68 (paras. 112-113), comp. pp. 64-65 (para. 104). 


\section{The understanding of other temporal references in the treaty}

In Aegean Sea Continental Shelf, ${ }^{174}$ the International Court of Justice was concerned with the interpretation of a reservation made by Greece to the 1928 General Act for the Pacific Settlement of International Disputes. The General Act conferred jurisdiction upon the Court to settle "[a]ll disputes with regard to which the parties are in conflict as to their respective rights". ${ }^{175}$ The reservation excluded from this jurisdiction, disputes relating to "the territorial status of Greece". As the Court held, "the territorial status of Greece" included any jurisdiction exercised by Greece over the continental shelf, although the concept of the continental shelf was totally unknown to international law in 1934 when Greece submitted its reservation. To explain why such an ambulatory approach to interpretation should be taken, the Court referred, among other things, to the commonly accepted understanding of Article 17 of the General Act:

If the Greek Government is correct, as it undoubtedly is, in assuming that the meaning of the generic term "rights" in Article 17 follows the evolution of the law, so as to be capable of embracing rights over the continental shelf, it is not clear why the similar term "territorial status" should not likewise be liable to evolve in meaning in accordance with "the development of international relations". ${ }^{176}$

The same kind of reasoning should apply with even greater force to two generic referring expressions when they both appear in one single treaty instrument. This makes Aegean Sea Continental Shelf highly relevant to the interpretation of tax treaties.

Tax treaties typically contain repeated reference to domestic legislation. To illustrate, in the latest OECD Model Convention, references to the law of the Contracting States can be found in Article 3, paragraph 2; in Article 4, paragraph 1; and in Article 6, paragraph 2. ${ }^{177}$ The question for an interpreter is whether such expressions are meant to re-

174 Aegean Sea Continental Shelf (Greece v. Turkey), Jurisdiction, Judgment of 19 December 1978, ICJ Reports 1978, p. 3.

175 Of course the agreed forum was not the ICJ, but the Permanent Court of International Justice (PCIJ). The General Act conferred jurisdiction upon the ICJ, because according to Article 37 of the Statute of the ICJ, whenever a treaty in force provides for reference of a dispute to the PCIJ, as between members of the UN, it shall be referred instead to the ICJ.

176 Ibid., p. 33 (para. 78).

177 Art. 3 establishes a series of general definitions; Art. 4 defines the concept of a resident; Art. 6 applies to taxes imposed on income from immovable property. fer to the laws in force at the time of the conclusion of the treaty or to the laws in force at whatever time the treaty is interpreted. The common understanding is that reference is consistently to the latter time. ${ }^{178}$ This observation helps establish the meaning of other expressions in a tax treaty, in the same way as the clear understanding of "rights" in Aegean Sea Continental Shelf helped the ICJ establish the meaning of "the territorial status of Greece". If some tax treaty parties conceived of a generic referring expression such as "the law of the Contracting State" as dynamic in nature, why should we assume that they conceived of other generic referring expressions differently?

\section{Possible "third party" effects of the treaty}

Most international agreements govern the conduct of states in their relations with other states and their various organs and officials. If Sweden were to conclude an agreement with Estonia delimiting the continental shelf between the two states in the Baltic Sea, for example, the agreement would work as a constraint on their respective governments with regard to any future claims to the continental shelf. If Germany and Sudan were both parties to the 1961 Vienna Convention on Diplomatic Relations, they would both have to afford protection to the diplomatic mission of the other party, including members of its staff. Tax treaties are of a different kind. Although, formally speaking, they establish a relationship between states-in the sense that no rights and obligations are conferred on any other than their respective parties-tax treaties intervene in relationships created under domestic legislation concerned with the conduct of state authorities vis-á-vis private subjects (taxpayers). Thus, the effects of the application of tax treaties are extensively those on the relationship between a state and third parties.

Now, just because a treaty bears on the interests of private subjects, it does not necessarily follow that at the conclusion of the treaty, the primary emphasis of its parties was on foreseeability and the creation of a stable legal relationship, as some commentators would like to have it. ${ }^{179}$ A distinction will have to be made between different public laws, depending on whether they confer rights or obligations. ${ }^{180}$ Democratic theory suggests that if a law has oner-

178 As concerns Art. 3(2) of the 2014 OECD Model Convention, this is already clarified explicitly in the text of the provision.

179 See e.g. Lang and Brugger (n. 1), pp. 103-104.

180 With regard to the interpretation of the ECHR, the Strasbourg Court would probably argue that the effective protection of human 
ous consequences for a person (NN), for this law to be legitimate, it would have to be introduced by a legislative assembly, the composition of which NN had the possibility of affecting (by taking part in free public elections, for instance). Certainly, tax treaties are relieving in character and, as such, do not urge states to introduce onerous legislation. At the same time, legislating belongs to the $d o$ maine reservée of sovereign states. No provision contained in a tax treaty will ever prevent a state from freely deciding how to implement its tax treaty obligations domestically, whether by piecemeal amendment of existing legislation or by a decision of parliament making the entire treaty part of domestic law. Seen in this light, any argument isolating the character of tax treaty law from the character of domestic tax law would generally seem to be synthetic. Consequently, insofar as concerns tax treaties concluded between states known for otherwise honoring democratic ideals, as we would insist, their third party effect works to inform interpretation. To establish the meaning of a generic referring expression, it would seem to make great sense to ask whether the respective parliaments of the two of more parties, when implementing tax treaty obligations domestically, could possibly acquaint themselves with the relevant institutional practice or practices-the language of international taxation, for instance. ${ }^{181}$ To state it more specifically, a concern over the democratic interest of the taxpayer is reason to assume that parties intended generic referring expressions to be defined by the OECD Commentaries existing at the time of conclusion of a tax treaty, rather than at whatever time the treaty is interpreted.

\section{Conclusions}

We began this essay by directing attention to arguments put forward by various experts in the course of the static/ambulatory-approaches debate. By having carefully analyzed and explained the international legal framework represented by Articles 31-33 of the VCLT, we hope to contribute to this debate. In short, our conclusions are as follows:

(1) What is the role of party intention in the application of Articles 31-33 of the VCLT, generally? When an act of interpretation is conducted according to Articles 31-33, it is always for the purpose of establishing the communicative

rights and fundamental freedoms necessarily implies an ambulatory approach.

181 Comp. Wattel and Marres (n. 1), pp. 223-224. intention of treaty parties - the meaning that the parties intended the treaty to communicate. As we argued, to be able to address properly the static/ambulatory-approaches debate, it is important first to understand that party intention is not a unitary concept. Most important, a distinction would have to be made between the communicative intentions of treaty parties and their referring intentions. Second, and also crucial to the debate, the communicative intention of treaty parties is a construct. The meaning of a treaty can only be assumed. It can only be understood on the assumption that treaty parties acted in conformity with some particular standard or standards of communication. Consequently, for the application of the law laid down in Articles 31-33, it is immaterial whether there was ever an actual intention of the parties or not. All that matters is what the text of the treaty gives reason to assume, looked upon from the perspective of the various means of interpretation.

(2) For the purpose of the interpretation of tax treaty law, how can the use of OECD Commentaries be justified based on international law? In contrast to the approach of many experts, as we argued, this question cannot be dealt with conclusively by the adoption of any one general principle. On the contrary, a proper answer presupposes that interpretation is done not only relative to a particular term or treaty provision, but also relative to the concrete facts of a specific dispute. As we concluded, justifications of the use of OECD Commentaries may be found in several provisions of the VCLT, depending on the situation. Consequently, Commentaries may help to determine the "ordinary meaning" of the terms of a tax treaty or its object and purpose, in the sense of Article 31, paragraph 1; Commentaries may come within the scope of application of Article 31, paragraph 3(b), either because they give report of the interpretation and application of tax treaties generally or because they form part of a "subsequent practice", in the sense of this same provision; finally, insofar as it can be established that a tax treaty was drafted on the basis of an OECD Model Convention, Commentaries accompanying this Model may form part of the circumstances of the conclusion of the treaty, in the sense of Article 32 of the VCLT.

(3) Considering the answer to question (2), should a static or an ambulatory approach be taken? As we argued, the answer to this question will inevitably depend on the particular rule of interpretation justifying the use of OECD Commentaries in a specific case. If Commentaries are used as part of the circumstances of the conclusion of a tax treaty, then because of the very nature of this means of interpretation, a static approach would have to be taken. If, instead, Commentaries are used to determine the ordi- 
nary meaning of the terms of a tax treaty or its object and purpose, or, if Commentaries are used based on Article 31, paragraph 3(b) of the VCLT, then the VCLT confers a discretion on interpreters. This discretion is not absolute in the sense that an interpreter can choose freely between a static and an ambulatory approach. Discretion is limited by the principle of good faith, which means that interpreters will have to continue their search for the communicative intention of treaty parties. Consequently, in the final analysis, every choice between a static or an ambulatory approach to the use of OECD Commentaries will have to be made on a case-by-case basis. We concluded this essay by suggesting a few general factors that may work as justification of such choices. 